\title{
Treatability Study of Tank E-3-1 Waste: Mixed Waste Stream SR-W049
}

by

C. A. Langton

Westinghouse Savannah River Company

RECORDS ADMINISTRATION

Savannah River Site

Aiken, South Carolina 29808

This paper was prepared in connection with work done under the above contract number with the U.S. Department of Energy. By acceptance of this paper, the publisher and/or recipient acknowledges the U.S. Government's right to retain a nonexclusive, royalty-free license in and to any copyright covering this paper, along with the right to reproduce and to authorize others to reproduce all or part of the copyrighted paper. 


\section{DISCLAIMER}

This report was prepared as an account of work sponsored by an agency of the United States Government. Neither the United States Government nor any agency thereof, nor any of their employees, makes any warranty, express or implied, or assumes any legal liability or responsibility for the accuracy, completeness, or usefulness of any information, apparatus, product, or process disclosed, or represents that its use would not infringe privately owned rights. Reference herein to any specific commercial product, process, or service by trade name, trademark, manufacturer, or otherwise does not necessarily constitute or imply its endorsement, recommendation, or favoring by the United States Government or any agency thereof. The views and opinions of authors expressed herein do not necessarily state or reflect those of the United States Government or any agency thereof.

This report has been reproduced directly from the best available copy.

Available to DOE and DOE contractors from the Office of Scientific and Technical Information, P. O. Box 62, Oak Ridge, TN 37831; prices available from (423) 576-8401.

Available to the public from the National Technical Information Service, U. S. Department of Commerce, 5285 Port Royal Road, Springfield, VA 22161. 


\title{
WESTINGHOUSE SAVANNAH RIVER COMPANY SAVANNAH RIVER TECHNOLOGY CENTER
}

\author{
KEY WORDS: \\ Mixed Waste \\ Waste Treatment
}

August 21,1997
CC: B. T. Butcher, 773-43A
W. E. Stevens, 773A
J. L. Siler 773-43A
L. T. Reid, 724-9E

To: M. F. Bullington, 724-9E

From: C. A. Langton, 773-43A

\section{TREATABILITY STUDY OF TANK E-3-1 WASTE: MIXED WASTE STREAM SR-W049}

\section{SUMMARY}

Treatability studies were conducted for tank E-3-1 waste which was previously characterized in WSRC-RP-97-0078. The waste was determined to be mixed waste because it displayed the characteristic of metal toxicity for $\mathrm{Hg}$ and $\mathrm{Cr}$ and was also contaminated with low levels of radionuclides.

Two types of treatments for qualifying this waste suitable for land disposal were evaluated: ion exchange and stabilization with hydraulic materials (portland cement, slag and magnesium phosphate cement). These treatments were selected for testing because:

1) Both treatments can be carried out as in-drum processes.

2) Cement stabilization is the RCRA/LDR best developed available technology (BDAT) for $\mathrm{Hg}$ (less than $280 \mathrm{mg} / \mathrm{L}$ ) and for $\mathrm{Cr}$.

3) Ion exchange via Mag-Sep is a promising alternative technology for in drum treatment of liquid wastes displaying metal toxicity.

Cement stabilization of the E-3-1 material ( supernate and settled solids) resulted in waste forms which passed the TCLP test for both $\mathrm{Hg}$ and $\mathrm{Cr}$. However, the ion exchange resins tested were ineffective in removing the $\mathrm{Hg}$ from this waste stream. Consequently, cement stabilization is recommended for a treatment of the five drums of the actual waste. 


\section{EXPERIMENTAL PROCEDURES}

\section{Ion Exchange Experiments}

Supernate (aqueous liquid) collected from Tank E-3-1 Drum 3-116-3 was used in the ion exchange experiments. This sample, 3-116-3-A (aqueous), was selected because it contained the highest concentration of mercury $(10.7 \mathrm{mg} / \mathrm{L})$ and was the only sample to exceed the TCLP limit for Cr of $5 \mathrm{mg} / \mathrm{L}$. Since all of the material in the five drums of Tank E-3-1 waste were taken from the same tank at the same time, only the sample with the highest concentration of mercury was used in the treatability testing. Results are expected to be applicable to all of the waste in all of the other drums as well as to that in Drum 3-116-3.

Since the speciation of the mercury in the E-3-1 waste was unknown, both anionic and cationic resins were selected to remove $\mathrm{Hg}$ from the aqueous portion. Resin GT-73 was selected for cationic $\mathrm{Hg}$ removal because it was demonstrated to be successful in previous laboratory testing and is being used in SRS processes, DPST 85-446. The Abmerlite IRA-400 resin was selected for anionic $\mathrm{Hg}$ removal based on recent laboratory experiments by J. Hage, SRTC, and the manufactures recommendation. Both resins are manufactured by Rhom and Haas.

The actual experiments were conducted to approximate an in-drum process. Resin GT-73 $(0.1 \mathrm{~g})$ was added to $100 \mathrm{~mL}$ of aqueous supernate from Drum 3-116-3. The amount of resin ws calculated to be more than enough to extract all of the $\mathrm{Hg}$ assuming that it was all in the cationic form. This material was stirred for 45 minutes and then filtered through a $0.45 \mathrm{um}$ filter. The filtrate was analyzed for total $\mathrm{Hg}$. Resin IRA- $400(0.1 \mathrm{~g})$ was also added to $100 \mathrm{~mL}$ of the same supernate. The mixture was again stirred for 45 minutes, then filtered to remove the resin. The filtrate was analyzed for $\mathrm{Hg}$.

\section{Cement Stabilization Experiments}

Two different chemical systems were selected for testing: 1) Magnesium phosphate cement developed by Argonne National Laboratory; and 2) Portland cement, i. e., calcium silicate based cement, with and without reducing agent modifiers. The proportions of the ingredients in the various mixes are listed in Table 2. Fly ash was used in the magnesium phosphate system to aid in the mixing action. Slag, $\mathrm{CaS}$, and $\mathrm{Na}_{2} \mathrm{SO}_{3}$ were added to the portland cement system to provide a chemically reducing environment in case the $\mathrm{Cr}$ was present as $\mathrm{Cr}^{+6}$. These reducing agents are used for the same purpose in tow SRS waste forms, Saltstone and the High Level Waste Tank Reducing Grout designed for waste encapsulation and tank filling.

The magnesium phosphate samples were prepared by adding all of the ingredients to the 3-116-3-A supernate and stirring by hand for 30 minutes. This relatively long stirring time is required to achieve the stabilization reactions with the hydrated phosphate phases. These samples set with in 4 hours. The portland cement samples were prepared in a 
similar manner except that they were stirred for 10 minutes. These samples set with in 24 hours. All stabilized samples cast in containers, sealed, and inspected for free water 2 and 24 hours after curing. The containers were kept sealed until the samples were prepared for the TCLP extraction

The cement waste forms were cured for 14 days in sealed containers and then prepared for the TCLP test. The TCLP test requires that solid material be crushed to pass a $3 / 8$ inch sieve prior to being extracted in acid leachate. The leachates were analyzed for the characteristic metals by an off site testing laboratory, GEL, Charleston SC. The Data sheets form GEL are attached..

\section{RESULTS AND DISCUSSION}

\section{Ion Exchange Experiments}

Results are presented in Table 1. The total mercury present in sample 3-116-3-A was measured as $10.7 \mathrm{mg} / \mathrm{L}$ in the characterization studies and as $7.7 \mathrm{mg} / \mathrm{L}$ in the treatability studies. This difference is probably due to a filtration step which was carried out prior to the analysis of the sample used in this treatability study. The results show that neither resin removed mercury from the aqueous liquid fraction of the waste stream. The analysis indicated that there was more $\mathrm{Hg}(0.5 \mathrm{mg} / \mathrm{L})$ in the treated sample than in the starting liquid. (This difference is considered within experimental error.) Results indicated that there was essentially no change in the $\mathrm{Hg}$ concentration of the starting material as the result of treatment with either resin.

In addition to using the ion exchange tests as part of the treatability study, these tests were also used to determine the speciation of the mercury in the waste. It appears that the mercury in the Tank E-3-1 supernate is present in a nonionic form, i. e., elemental, complexed as a neutral species or amalgamated, since neither ionic resin was successful in removing it.

\section{Stabilization Experiments}

All of the stabilized waste forms passed the TCLP test for Hg and Cr. Results are presented in Table 2. None of the stabilized samples had bleed water (free, drainable water) 24 hours after mixing.

\section{CONCLUSIONS}

The Tank E-3-1 waste stream consists of five partially full 55 gallon drums. This waste stream SR-W049 is classified as mixed because it displays the characteristic of metal $(\mathrm{Hg}$ and $\mathrm{Cr}$ ) toxicity. Four of the drums contain settled solids and supernate. One drum contains only supernate. At least one of the drums contains a small amount or debris.

In drum processing is appropriate for stabilizing this waste provided that the settled solids can be slurried with the supernate and provided that the containers meet the 
corrosion/integrity requirements for disposal. Two types of in-drum processing were evaluated, stabilization and ion exchange.

Stabilization is effective in treating the Tank E-3-1 waste stream. Portland cement and magnesium phosphate cement were tested and both systems produced waste forms which passed the TCLP test. The TCLP and Universal Treatment Standard (UTS) limits for Hg and $\mathrm{Cr}$ are reported in Table 2 for comparison. Both sets of limits are reported because this waste stream may be treated after the UTS goes into effect.

Experiments performed in this study were conducted on a laboratory bench scale. Scale up to a 55 gallon experiment or process is expected to be straight forward. At the time of sampling, the settled solids were not compacted to the point of being difficult to sample. Consequently it is expected that mixing with an in drum recirculating or a paddle mixer will be sufficient to achieve a slurry. The stabilizing reagents (cement and additives) can be added to the top of the drums and blended into the waste slurry.

The only issue identified is one of corrosion of the disposal containers if in drum mixing is used. It should be noted that cement waste forms contain a small amount of water in the pores of the solidified material. The pore water is not drainable, but it is available for evaporation and subsequent condensation on the inner drum surfaces. Consequently, the disposal drums should be lined with plastic liners to minimize the potential for corrosion of the steel containers. Localized drum corrosion (pitting) and container failures have been encountered for cement waste forms at SRS (Naval Fuel cement based waste forms) and at other DOE sites (Oak ridge, K-25 cemented pond sludge).

The mercury in the aqueous portion of the E-3-1 waste stream appears to be nonionic because it could not be removed by anionic or cationic ion exchange resins which are very effective in binding mercury. Therefore, in drum ion exchange is not recommended for treatment of this waste stream. Since ion exchange is the mercury removal process in the SRS Effluent treatment Facility, ETF, this facility is appropriate for the E-3-1 supernate provided that effective blending with other low mercury waste streams can be assured. Since the quantity of supernate in the E-3-1 stream is less than 250 gallons, blending for ETF is an option.

\section{RECOMMENDATIONS}

Stabalize the Tank E-3-1 waste stream (SR-W049) with a portland cement or magnesium phosphate cement to meet the TCLP metals concentration limits. (The proportions of the stabilization ingredients will be approximately those listed in Table 2 for the bench scale studies.) This will allow the resulting waste forms to be disposed of as non hazardous, low-level radioactive waste.

For long term container integrity, 90 mil plastic liners with lids or other types of compatible liners should be used for disposal of the cement waste forms. (The magnesium phosphate system is reported to result in a waste form with no evaporable 
pore water, Dileep Singh, Argonne National Laboratory. Consequently, the magnesium phosphate waste form may have a long term advantage with respect to container corrosion.)

The five drums of tank E-3-1 waste can be treated through one of the following options:

- In drum ashcrete processing at the CIF;

- In drum processing in N-Area.

- Treatability studies or processing at Argonne National Laboratory in their existing in drum mixer for magnesium phosphate waste forms. (The technical contact at Argonne is Dileep Singh.)

- Treatability studies or processing at INEL.

- Vendor stabilization. Potential vendors include Chem Nuclear or SEG

- ETF processing.

\section{REFERENCES}

C. A. Langton, Characterization of Tank E-3-1-: Mixed Waste Stream SR-W049 (U), WSRC-RP-97-0078, 2-21-97.

J. P. Bibler, EP-Toxicity Test of Saturated GT-73 Resin and Resin in Grout, DPST-85- 446, 4-24-85.

J. Hage, WSRC-NB-96-703.

Table 1. Results of Ion Exchange Treatment of E-3-1 liquid.

E-3-1 Waste Sample Description Drum 3-116-1-A (liquid)
Before Treatment After Treatment Effect of Treatment $[\mathrm{Hg}] \mathrm{mg} / \mathrm{L}$ $[\mathrm{Hg}] \mathrm{mg} / \mathrm{L}$ change

\begin{tabular}{|c|c|c|c|c|}
\hline $\begin{array}{c}\text { (liquid) } \\
\text { (116-1-A }\end{array}$ & none & 7.7 & $\ldots$ & \\
\hline & $\begin{array}{c}\text { GT-73 } \\
\text { (cationic) }\end{array}$ & 7.7 & 8.2 & +0.5 \\
\hline & $\begin{array}{c}\text { IRA-400 } \\
\text { (anionic) }\end{array}$ & 7.7 & 7.8 & +0.1 \\
\hline
\end{tabular}


Table 2. Results of Stabilization Treatment of E-3-1 Liquid.

\begin{tabular}{|c|c|c|c|}
\hline \multicolumn{4}{|c|}{$\begin{array}{c}\text { Stabilization Treatment } \\
\text { Waste Form }\end{array}$} \\
\hline Sample No. & Ingredients & $\begin{array}{c}\operatorname{\Gamma CLP}[\mathrm{Hg}] \\
(\mathrm{mg} / \mathrm{L})\end{array}$ & $\begin{array}{c}\text { TCLP }[\mathbf{C r}] \\
(\mathbf{m g} / \mathbf{L})\end{array}$ \\
\hline 3 & $\begin{array}{c}\text { E-3-1 liquid } \\
\mathrm{MgO} \\
\mathrm{KH}_{2} \mathrm{PO}_{4} \\
\text { Class F Fly Ash } \\
\end{array}$ & 0.00095 & 0.0130 \\
\hline 4 & $\begin{array}{c}\text { E-3-1 liquid } \\
\mathrm{MgO} \\
\mathrm{KH}_{2} \mathrm{PO}_{4} \\
\text { Slag }\end{array}$ & 0.00011 & 0.0086 \\
\hline I & $\begin{array}{l}\text { E-3-1 Liquid } \\
\text { Type I Portland } \\
\text { Cement } \\
\end{array}$ & 0.00007 & 0.0573 \\
\hline II & $\begin{array}{l}\text { E-3-1 Liquid } \\
\text { Type I Portland } \\
\text { Cement }\end{array}$ & 0.000130 & 0.152 \\
\hline IV & $\begin{array}{c}\text { E-3-1 Liquid } \\
\text { Type I Port. Cem. } \\
\text { CaS reagent grade } \\
\end{array}$ & 0.00212 & 0.429 \\
\hline V & $\begin{array}{l}\text { E-3-1 Liquid } \\
\text { Type I Port. Cem. } \\
\mathrm{Na}_{2} \mathrm{~S}_{2} \mathrm{O}_{3} \\
\end{array}$ & 0.00204 & 0.291 \\
\hline VII & $\begin{array}{c}\text { E-3-1 Liquid } \\
\text { Type I Port. Cem. } \\
\text { Slag } \\
\mathrm{Na}_{2} \mathrm{~S}_{2} \mathrm{O}_{3} \\
\end{array}$ & 0.00076 & 0.0515 \\
\hline TCLP limit & - & 0.2 & 5.0 \\
\hline UTS limit & - & 0.025 & 0.86 \\
\hline
\end{tabular}




\section{ATTACHMENT 1}

Analytical Results from General Engineering Laboratories 


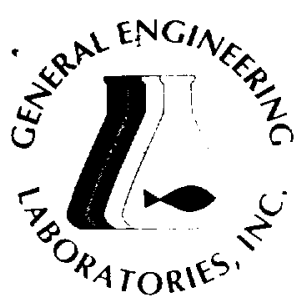

\title{
GENERAL ENGINEERING LABORATORIES
}

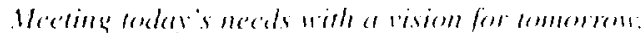

\author{
CASE NARRATIVE REPORT \\ for \\ Westinghouse Savannah River Site \\ Subcontract No. AB93796N \\ EGG150
}

August 26, 1997

Laboratory Identification:

General Engineering Laboratories, Inc.

\section{Summary:}

Sample receipt

Eight solid samples for Westinghouse Savannah River Site arrived at General Engineering Laboratories, Inc., (GEL) Charleston, South Carolina on August 13, 1997, for analysis. All samples listed on the chain arrived without any visible signs of tampering. A 3 day turnaround for results was requested on the chain of custody. The results were faxed on August 18, 1997. Because the arsenic and selenium were not analyzed by graphite furnace as requested, the samples were relogged and analyzed on August 21,1997 . The data included in this data package reflects the graphite furnance results.

The temperature of the samples was $2^{\circ} \mathrm{C}$. The sample was stored properly according to SW-846 procedures and GEL Standard Operating Procedures (SOP).

The following samples were received by the laboratory:

\begin{tabular}{ll} 
Description & Sample Number \\
\hline MLX I & $9708249-01$ \\
MIX II & $9708249-02$ \\
MIX III & $9708249-03$ \\
MIX IV & $9708249-04$ \\
MIX V & $9708249-05$ \\
MIX VI & $9708249-06$ \\
SAMPLE 3 & $9708249-07$ \\
SAMPLE 4 & $9708249-08$
\end{tabular}

\section{Case Narrative}

Sample analyses were conducted using methodology as outlined in General Engineering Laboratories (GEL) Standard Operating Procedures. Any technical or administrative problems during analysis, data review, and reduction are written by analytical fraction in the enclosed narratives.

\section{Data Package:}

The enclosed data package contains the following sections: Case Narrative, Level II Certificate of Analysis, QC Sample Summaries, Chain of Custody, Sample Tracking Report. Nonconformance Reports if applicable \& Electronic Data Hardcopy Report. 
Case Narrative - Westinghouse Savannah River Site

August 26, 1997

EGG 150

page 2 of 4

The Level II Certificate of Analysis contains the following headings:

Sample ID:

Lab ID:

Matrix:

Date Collected:

Date Received:

Priority:

Collector:
Sample Identification

This is the laboratory identification number

Sample matrix

Date of sample collection

Date of sample receipt by the laboratory

Internal status of sample turnaround

Party responsible for sample collection.

The detail on the Certificate includes the following:

Parameter:

Qualifier:

Result:

DL:

RL:

Units:

DF:

Analyst:

Date:

Time:

Batch:

Method:

Surrogate Recovery:

Test:

Percent \%:

Acceptable Limits:
Analyte or characteristic tested for in the sample

Qualifier used for data interpretation

Final result of each parameter.

Method Detection Limit

Reporting Limit

Units of final result

Dilution factor

Initials of analyst who performed the test

Date of analysis

Time of analysis

Analytical batch in which the sample was analyzed

Analytical method used for the analysis of the sample. Identified on the report numerically with a corresponding table.

Provided for organics analysis only. Surrogate compound identified.

Analytical test associated with surrogate compound.

Surrogate percent recovery

Limits established for surrogate recoveries based upon the method requirements.

The QC Summary Report contains the following headings:

Sample Parameter:

Type:

Batch:

NOM:

Sample:

QC:

Units:

RPD\%:

REC\%:

Range:

Analyst:

Date:

Time:
Analyte or characteristic tested for in the $\mathrm{QC}$ sample

Type of QC sample (i.e., blank, dup, LCS, LCS dup, MS, MSD)

Analytical batch in which the $Q C$ sample was analyzed

Nominal concentration of the spiking compound

Amount of compound found in the sample associated with the QC sample.

Amount of compound found in the QC sample.

Units of final result

Relative percent difference between LCS/LCS dup, MS/MSD, and Sample/Sample duplicate

Recovery for the control samples

Acceptance limits for control samples

Intials of analyst who performed the test

Date of analysis

Time of analysis 
August 26, 1997

EGG 150

page 3 of 4

Types of QC samples that may be found on the QC Summary Report are:

$\begin{array}{ll}\text { Blank: } & \text { Results of the blank analysis for the sample batch } \\ \text { Dup: } & \text { Duplicate analysis of sample } \\ \text { LCS: } & \text { Lab control sample } \\ \text { LCS dup: } & \text { Lab control sample duplicate } \\ \text { MS: } & \text { Matrix spike } \\ \text { MSD: } & \text { Matrix spike duplicate }\end{array}$

The following are definitions of reporting limits used at General Engineering Laboratories:

DL Detection Limit: The minimum level of an analyte that can be determined (identified not quantified) with $99 \%$ confidence. The values are normally achieved by preparing and analyzing seven aliquots of laboratory water spiked 1 to 5 times the estimated MDL, taking the standard deviation and multiplying it against the one-tailed t-statistic at $99 \%$. This computed value is then verified for reasonableness by repeating the study using the concentration found in the initial study, calculating an F-ratio, and computing the final limit. Sample specific preparation and dilution factors are applied to these limits when they are reported.

The detection limit is the minimum concentration of a substance that can be identified, measured, and reported with $99 \%$ confidence that the analyte concentration is above zero. It answers the question "Is It Present".

QL Quantitation Limit: The lowest concentration that can be reliably achieved within specified limits of precision and accuracy during routine laboratory operating conditions. The QL is generally 5 to 10 times the MDL. However, it may be nominally chosen within these guidelines to simplify data reporting. For many analytes the QL analyte concentration is selected as the lowest non-zero standard in the calibration curve. Sample QL's are highly matrix-dependent. Sample specific preparation and dilution factors are applied to these limits when they are reported

The $\mathrm{QL}$ is always $\geq \mathrm{DL}$

RL . Reporting Limit: Same as the QL except where driven by contract or client specifications. If the sample specific preparation and dilution factors cause the QL to be elevated above the RL, then the QL is used as the RL.

The quantitation limit is the lowest level at which a chemical may be accurately and reproducibly quantitated. It answers the question "HOW MUCH IS PRESENT".

Interpretation of RESLLT column on the Certificate of Analysis:

If the final concentration in the sample was found to be above the RL, then the value reported is reported without a flag; 
August 26, 1997

EGG 150

page 4 of 4

If the final concentration in the sample was found to be below the RL but above the DL, then the value reported is flagged with a "J";

If the final concentration in the sample was found to be below the DL, the value reported is flagged with a "U".

\section{Quality Control Flags}

General Engineering Laboratories maintains acceptance criteria for QC samples through use of statistical process control (SPC). The SPC limits are used to qualify data usability. The flagging criteria identified in WSRC AN95 Format does not necessarily coincide with the laboratory SPC criteria. There may be instances where the Electronic Data Deliverable (EDD) has flagged data based on the AN95 criteria and the lab has not identified the data to be outside of established control limits.

Those instances where the QC has not met laboratory SPC established criteria will be noted in the section case narratives that are included in this package.

This data package, to the best of my knowledge, is in compliance with technical and administrative requirements.

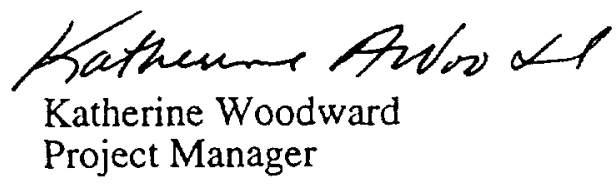

wsrc00194.EGG150 


\section{Case Narrative \\ for \\ Westinghouse Savannah River Co. \\ EGG150 \\ 9708249}

Analytical Batch Number: 106762

Analytical Method: EPA 7060,EPA 7740

Laboratory Number

9708249-01

9708249-02

9708249-03

9708249-04

9708249-05

9708249-06

9708249-07

9708249-08
Sample Description

MIX I

MIX II

MIX III

MIX IV

MIX V

MIX VI

SAMPLE 3

SAMPLE 4

\section{Sample Preparation:}

All samples were prepared in accordance with accepted procedures.

\section{Instrument Calibration:}

The instrument was properly calibrated.

\section{Holding Time}

All samples were run within the required holding time.

\section{Blanks:}

No target analytes were detected in the method blank above the required acceptance limit.

\section{Spike Analyses:}

The matrix spikes were run on the following Sample Number.

$$
\text { 9708249-07 }
$$

Acceptance limits are not applicable for TCLP spikes.

\section{Laboratory Control Samples:}

All analyte recoveries in the laboratory control sample were within the required acceptance limits. 


\section{Dilutions:}

The following samples were diluted 1:20 due to matrix.

\section{Laboratory Number}

$$
\begin{aligned}
& 9708249-01 \\
& 9708249-02 \\
& 9708249-04 \\
& 9708249-05 \\
& 9708249-06 \\
& 9708249-07 \\
& 9708249-08
\end{aligned}
$$




\section{Case Narrative \\ for \\ Westinghouse Savannah River Co. \\ EGG150 \\ 9708249}

Analytical Batch Number: 106513

Analytical Method: EPA 7470,EPA 7471

\begin{tabular}{cll} 
Laboratory Number & & \\
\cline { 3 - 3 } $9708249-01$ & & MIX I \\
$9708249-02$ & & MIX II \\
$9708249-03$ & & MIX III \\
$9708249-04$ & & MIX IV \\
$9708249-05$ & & MIX V \\
$9708249-06$ & & MIX VI \\
$9708249-07$ & & SAMPLE 3 \\
$9708249-08$ & & SAMPLE 4
\end{tabular}

\section{Sample Preparation:}

Sample Description

All samples were prepared in accordance with accepted procedures.

\section{Instrument Calibration:}

The instrument was properly calibrated.

\section{Holding Time:}

All samples were analyzed within the required holding time.

\section{Blanks:}

No target analytes were detected in the method blank above the required acceptance limit.

\section{Spike Analyses:}

The matrix spikes were run on the following Sample Number.

9708249-01

Acceptance limits are not applicable for TCLP spikes.

\section{Laboratory Control Samples:}

All analyte recoveries in the laboratory control sample were within the required acceptance limits.

All analytes in the laboratory control sample duplicate were within the required acceptance limits for relative percent difference. 


\section{Sample Duplicates:}

All sample duplicate results were within the required acceptance limits.

\section{Dilutions:}

None of the samples were diluted.

\section{Non Conformance Reports:}

The following Nonconformance Reports were written for this batch.

NCR\# GEL-AS-MA-988. 


\section{Case Narrative \\ for \\ Westinghouse Savannah River Co. \\ EGG150 \\ 9708249}

Analytical Batch Number: 106517

Analytical Method: EPA 6010A,SW846 6010A

Laboratory Number

9708249-01

9708249-02

9708249-03

9708249-04

9708249-05

9708249-06

9708249-07

9708249-08
Sample Description

MIX I

MIX II

MIX III

MIX IV

MIX V

MIX VI

SAMPLE 3

SAMPLE 4

\section{Sample Preparation:}

All samples were prepared in accordance with accepted procedures.

\section{Instrument Calibration:}

The instrument was properly calibrated.

\section{Holding Time:}

All samples were analyzed within the required holding time.

\section{Blanks:}

No target analytes were detected in the method blank above the required acceptance limit.

\section{Spike Analyses:}

The matrix spikes were run on the following Sample Number.

$$
\text { 9708249-08 }
$$

Acceptance limits are not applicable for TCLP spikes.

\section{Laboratory Control Samples:}

All analyte recoveries in the laboratory control sample were within the required acceptance limits.

All analytes in the laboratory control sample duplicate were within the required acceptance limits for relative percent difference. 


\section{Sample Duplicates:}

All sample duplicate results were within the required acceptance limits.

\section{Dilutions:}

None of the samples were diluted.

\section{Non Conformance Reports:}

There were no Nonconformance Reports associated with this batch. 


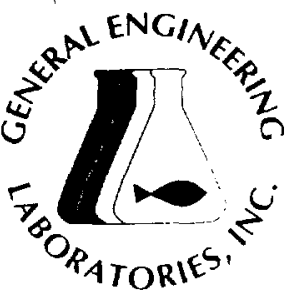

Client: Westinghouse Savannah River Co.

Building 773-58A, Room 1

P.O. Box 616

Aiken, South Carolina 29802

Contact:

Project Description:

œ: WSRC00497

Hazardous Waste Contract

\section{GENERAL ENGINEERING LABORATORIES}

Mecting todes's needs with a rision for momorom

page 18

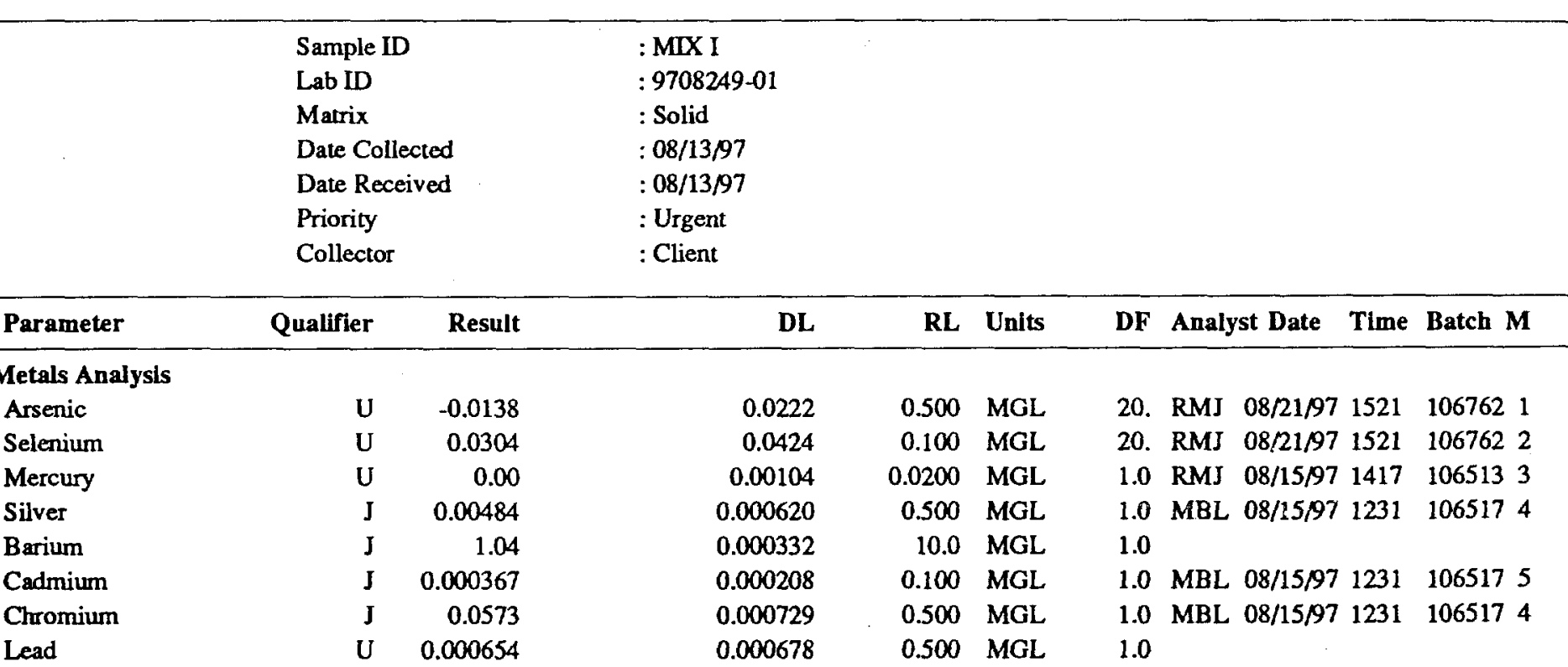

The following prep procedures were performed:

Mercury

CRB $\quad 08 / 14 / 97 \quad 1800 \quad 106513 \quad 3$

TCLP Prep (Metals, Prep Only)

JL $\quad 08 / 13 / 971915 \quad 1064266$

\begin{tabular}{ll}
\hline M = Method & Method-Description \\
\hline M 1 & EPA 7060 \\
M 2 & EPA 7740 \\
M 3 & EPA 7470 \\
M 4 & SW846 6010A \\
M 5 & EPA 6010A \\
M 6 & EPA 1311M
\end{tabular}




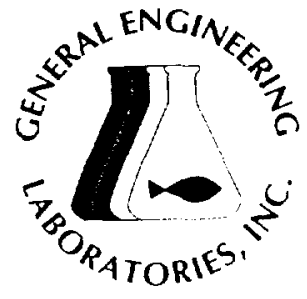

Client: Westinghouse Savannah River Co. Building 773-58A, Room 1

P.O. Box 616

Aiken, South Carolina 29802

Contact: $\quad$ Ms. Janet Crawford

Project Description:

cc: WSRC00497
WSRC-RP-97-00761

page 19

\begin{tabular}{lll}
\multicolumn{3}{c}{ Laboratory Certifications } \\
STATE & GEL & EPI \\
FL & E87156/87294 & E87472/87458 \\
NC & 233 & \\
SC & 10120 & 10582 \\
TN & 02934 & 02934
\end{tabular}

\begin{tabular}{lcc}
\hline Sample ID & $:$ MIX I \\
\hline$M=$ Method & Method-Description \\
\hline
\end{tabular}

\section{Notes:}

The qualifiers in this report are defined as follows:

ND indicates that the analyte was not detected at a concentration greater than the detection limit.

$J$ indicates presence of analyte at a concentration less than the reporting limit (RL) and greater than the detection limit (Dl,).

$U$ indicates that the analyte was not detected at a concentration greater than the detection limit.

* indicates that a quality control analyte recovery is outside of specified acceptance criteria.

This data report has been prepared and reviewed

in accordance with General Engineering Laboratories

standard operating procedures. Please direct

any questions to your Project Manager, Kate Woodward at (803) 769-7376.

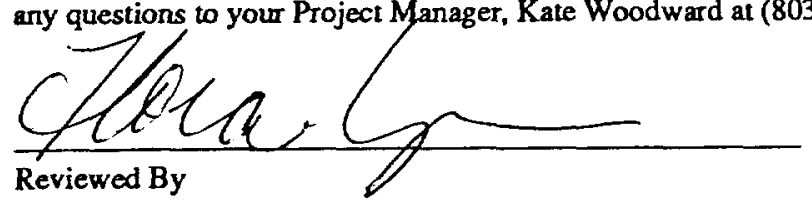




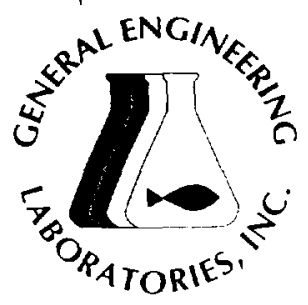

Client: Westinghouse Savannah River Co.

Building 773-58A, Room 1

P.O. Box 616

Aiken, South Carolina 29802

Contact: Ms. Janet Crawford

Project Description:

cc: WSRC00497

Hazardous Waste Contract
WSRC-RP-97-00761

page 20

GENERAL ENGINEERING LABORATORIES

Meering todar's needs with a risiom for tomormon

Report Date: August 26, 1997

Page 1 of 2

$\begin{array}{ll}\text { Sample ID } & : \text { MIX II } \\ \text { Lab ID } & : 9708249-02 \\ \text { Matrix } & : \text { Solid } \\ \text { Date Collected } & : 08 / 13 / 97 \\ \text { Date Received } & : 08 / 13 / 97 \\ \text { Priority } & : \text { Urgent } \\ \text { Collector } & : \text { Client }\end{array}$

\begin{tabular}{|c|c|c|c|c|c|c|c|c|c|}
\hline Parameter & Qualifier & Result & DL & $\mathbf{R L}$ & Units & DF & Analyst Date & Time & Batch M \\
\hline \multicolumn{10}{|c|}{ Metals Analysis } \\
\hline Arsenic & $\mathrm{U}$ & -0.00320 & 0.0222 & 0.500 & MGL & 20. & RMJ $08 / 21 / 97$ & 1526 & 1067621 \\
\hline Selenium & $\mathrm{U}$ & 0.0374 & 0.0424 & 0.100 & MGL & 20. & RMJ $08 / 21 / 97$ & 1526 & 1067622 \\
\hline Mercury & $\mathrm{U}$ & 0.000130 & 0.00104 & 0.0200 & MGL & 1.0 & RMJ $08 / 15 / 97$ & 1419 & 1065133 \\
\hline Silver & J & 0.00124 & 0.000620 & 0.500 & MGL & 1.0 & MBL $08 / 15 / 97$ & 1306 & 1065174 \\
\hline Barium & J & 0.626 & 0.000332 & 10.0 & MGL & 1.0 & & & \\
\hline Cadmium & $\mathrm{U}$ & 0.000146 & 0.000208 & 0.100 & MGL & 1.0 & MBL $08 / 15 / 97$ & 1306 & 1065175 \\
\hline Chromium & J & 0.152 & 0.000729 & 0.500 & MGL & 1.0 & MBL 08/15/97 & 1306 & 1065174 \\
\hline Lead & $\mathbf{J}$ & 0.00130 & 0.000678 & 0.500 & MGL & 1.0 & & & \\
\hline
\end{tabular}

The following prep procedures were performed:

Mercury

CRB $\quad 08 / 14 / 97 \quad 1800 \quad 106513 \quad 3$

TCLP Prep (Metals, Prep Only)

\begin{tabular}{ll}
\hline M Method & Method-Description \\
\hline M1 & EPA 7060 \\
M2 & EPA 7740 \\
M3 & EPA 7470 \\
M4 & SW846 6010A \\
M 5 & EPA 6010A \\
M6 & EPA 1311M
\end{tabular}




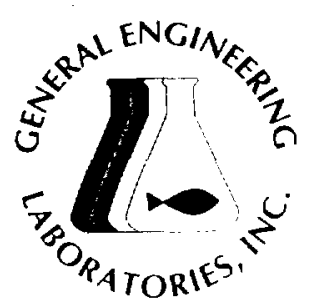

Client:

Project Description:

\section{GENERAL ENGINEERING LABORATORIES}

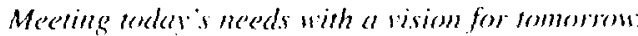

$\begin{aligned} \text { Client: } & \text { Westinghouse Savannah River Co. } \\ & \text { Building 773-58A, Room 1 } \\ & \text { P.O. Box 616 } \\ & \text { Aiken, South Carolina } 29802 \\ & \text { Ms. Janet Crawford } \\ \text { Project Description: } & \text { Hazardous Waste Contract }\end{aligned}$

Report Date: August 26, 1997

Page 2 of 2

cc: WSRC00497

\begin{tabular}{lll}
\multicolumn{3}{c}{ Laboratory Certifications } \\
STATE & GEL & EPI \\
FL & E87156/87294 & E87472/87458 \\
NC & 233 & \\
SC & 10120 & 10582 \\
TN & 02934 & 02934
\end{tabular}

\begin{tabular}{lll}
\hline & Sample ID & :MIX II \\
\hline$M=$ Method & Method-Description \\
\hline
\end{tabular}

Notes:

The qualifiers in this report are defined as follows:

ND indicates that the analyte was not detected at a concentration greater than the detection limit.

$\mathrm{J}$ indicates presence of analyte at a concentration less than the reporting limit (RL) and greater than the detection limit (DL).

$\mathrm{U}$ indicates that the analyte was not detected at a concentration greater than the detection limit.

* indicates that a quality control analyte recovery is outside of specified acceptance criteria.

This data report has been prepared and reviewed

in accordance with General Engineering Laboratories

standard operating procedures. Please direct

any questions to your Project Manager, Kate Woodward at (803) 769-7376.

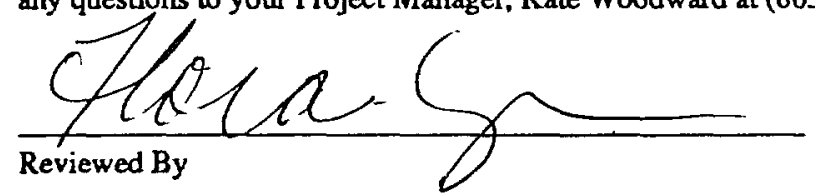




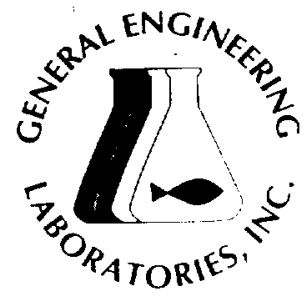

Client: Westinghouse Savannah River Co.

Building 773-58A, Room 1

P.O. Box 616

Aiken, South Carolina 29802

Contact:

Project Description:

cc: WSRC00497
WSRC-RP-97-00761

page 22

GENERAL ENGINEERING LABORATORIES

Meeting wader's needs with a wision for tomormon:

$\begin{array}{ll}\text { Sample ID } & : \text { MIX III } \\ \text { Lab ID } & : 9708249-03 \\ \text { Matrix } & : \text { Solid } \\ \text { Date Collected } & : 08 / 13 / 97 \\ \text { Date Received } & : 08 / 13 / 97 \\ \text { Priority } & : \text { Urgent } \\ \text { Collector } & : \text { Client }\end{array}$

\begin{tabular}{|c|c|c|c|c|c|c|c|c|c|}
\hline Parameter & Qualifier & Result & DL & $\mathbf{R L}$ & Units & DF & Analyst Date & Time & Batch M \\
\hline \multicolumn{10}{|c|}{ Metals Analysis } \\
\hline Arsenic & $\mathrm{U}$ & -0.00120 & 0.0222 & 0.500 & MGL & 1.0 & RMJ $08 / 21 / 97$ & 1532 & 1067621 \\
\hline Selenium & U & 0.0284 & 0.0424 & 0.100 & MGL & 1.0 & RMJ $08 / 21 / 97$ & 1532 & 1067622 \\
\hline Mercury & $\mathrm{U}$ & 0.000450 & 0.00104 & 0.0200 & MGL & 1.0 & RMJ 08/15/97 & 1422 & 1065133 \\
\hline Silver & $\mathbf{J}$ & 0.00100 & 0.000620 & 0.500 & MGL & 1.0 & MBL 08/15/97 & 1311 & 1065174 \\
\hline Barium & $\mathbf{J}$ & 0.589 & 0.000332 & 10.0 & MGL & 1.0 & & & \\
\hline Cadmium & J & 0.000216 & 0.000208 & 0.100 & MGL & 1.0 & MBL $08 / 15 / 97$ & 1311 & 1065175 \\
\hline Chromium & J & 0.149 & 0.000729 & 0.500 & MGL & 1.0 & MBL $08 / 15 / 97$ & i311 & 1065174 \\
\hline Lead & $J$ & 0.00102 & 0.000678 & 0.500 & MGL & 1.0 & & & \\
\hline
\end{tabular}

The following prep procedures were performed:

Mercury

CRB 08/14/97 $1800 \quad 1065133$

TCLP Prep (Metals, Prep Only)

Л $\quad 08 / 13 / 9719151064266$

\begin{tabular}{ll}
\hline M = Method & Method-Description \\
\hline M 1 & EPA 7060 \\
M 2 & EPA 7740 \\
M3 & EPA 7470 \\
M 4 & SW846 6010A \\
M 5 & EPA 6010A \\
M 6 & EPA 1311M
\end{tabular}

PO Box 30712 • Charleston, SC 29417 • 2040 Savage Road • 29407 


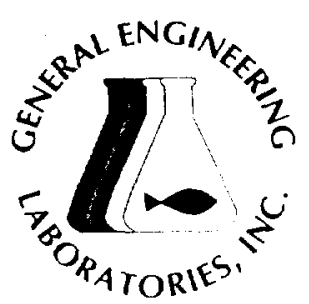

Client:

Contact:

Project Description:
GENERAL ENGINEERING LABORATORIES

Me'ting trodar's needs with a wision for somorom:

\begin{tabular}{lll}
\multicolumn{3}{c}{ Leboralory Certificalions } \\
STATE & GEL & EPI \\
FL & E87156/87294 & E87472/87458 \\
NC & 233 & \\
SC & 10120 & 10582 \\
TN & 02934 & 02934
\end{tabular}

cc: WSRC00497

Sample ID : MIX III

Notes:

The qualifiers in this report are defined as follows:

ND indicates that the analyte was not detected at a concentration greater than the detection limit.

$J$ indicates presence of analyte at a concentration less than the reporting limit (RL) and greater than the detection limit (DL).

$\mathrm{U}$ indicates that the analyte was not detected at a concentration greater than the detection limit.

* indicates that a quality control analyte recovery is outside of specified acceptance criteria.

This data report has been prepared and reviewed

in accordance with General Engineering Laboratories

standard operating procedures. Please direct

any questions to your Project Manager, Kate Woodward at (803) 769-7376.

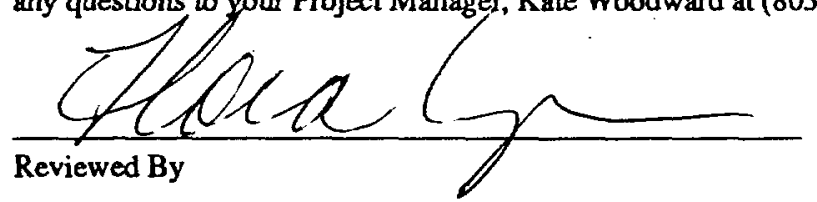




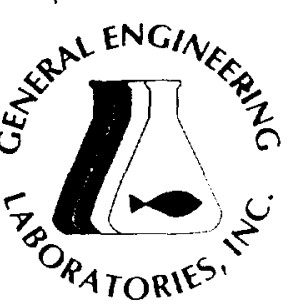

$\begin{array}{cl}\text { Client: } & \text { Westinghouse Savannah River Co. } \\ & \text { Building 773-58A, Room 1 } \\ & \text { P.O. Box 616 } \\ & \text { Aiken, South Carolina 29802 } \\ \text { Contact: } & \text { Ms. Janet Crawford } \\ \text { scription: } & \text { Hazardous Waste Contract }\end{array}$

Client: Westinghouse Savannah River Co.

Project Description

cc: WSRC00497
P.O. Box 616

Ms. Janet Crawford

\section{GENERAL ENGINEERING LABORATORIES}

Mecting todas is meeds with a rivion for tomowron:

Report Date: August 26, 1997
WSRC-RP-97-00761

page 24

\begin{tabular}{lll}
\multicolumn{3}{c}{ Laboratory Certifications } \\
STATE & GEI & EPI \\
FL & E87156/87294 & E87472/87458 \\
NC & 233 & \\
SC & 10120 & 10582 \\
TN & 02934 & 02934
\end{tabular}

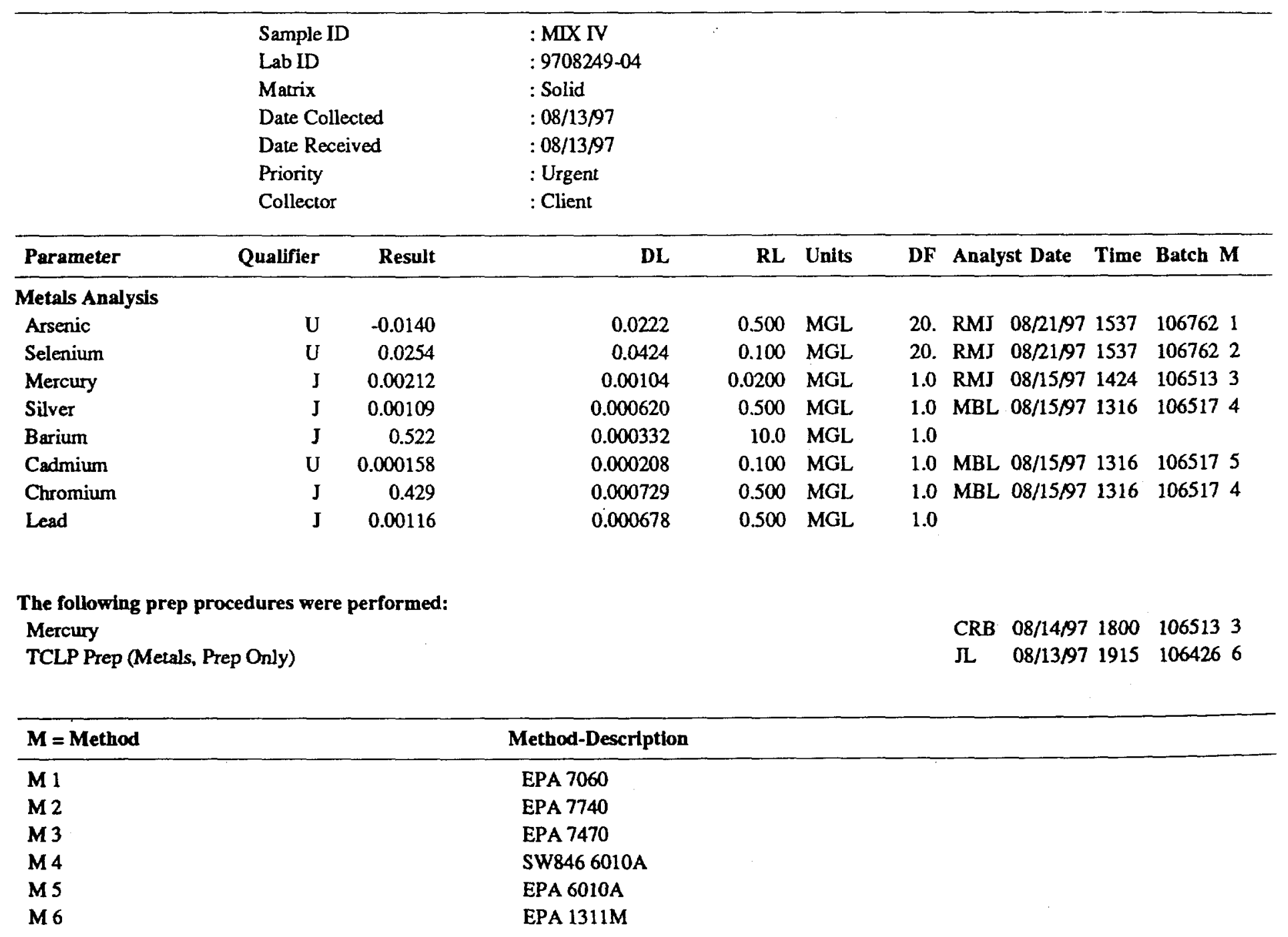




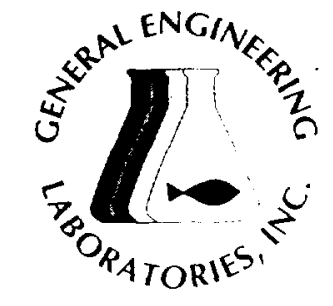

Client: Westinghouse Savannah River Co.

Building 773-58A, Room 1

P.O. Box 616

Aiken, South Carolina 29802

Contact: Ms. Janet Crawford

Project Description:

cc: WSRC00497

Hazardous Waste Contract
WSRC-RP-97-00761

page 25

\section{GENERAL ENGINEERING LABORATORIES}

Mecting todar's needs with a wision for tomonsm
Laboratory Certifications

STATE GEI, EPI

FL $\quad E 87156 / 87294 \quad$ E87472/87458

NC 233

SC $10120 \quad 10582$

\begin{tabular}{lcc}
\hline & Sample ID & MIX IV \\
\hline$M=$ Method & Method-Description \\
\hline
\end{tabular}

Notes:

The qualifiers in this report are defined as follows:

ND indicates that the analyte was not detected at a concentration greater than the detection limit.

$J$ indicates presence of analyte at a concentration less than the reporting limit (RL) and greater than the detection limit (DL).

$U$ indicates that the analyte was not detected at a concentration greater than the detection limit.

* indicates that a quality control analyte recovery is outside of specified acceptance criteria.

This data report has been prepared and reviewed

in accordance with General Engineering Laboratories

standard operating procedures. Please direct

any questions to your Project Manager, Kate Woodward at (803) 769-7376.

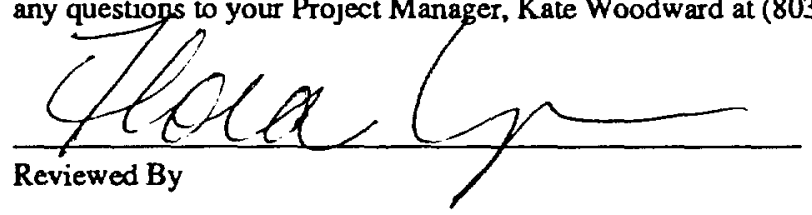




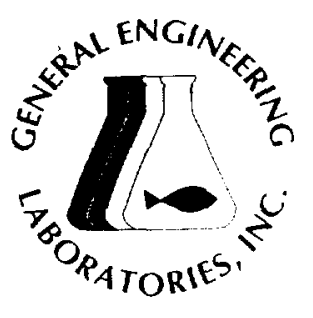

Client: Westinghouse Savannah River Co.

Building 773-58A, Room 1

P.O. Box 616

Aiken, South Carolina 29802

Contact:

Project Description:
GENERAL ENGINEERING LABORATORIES

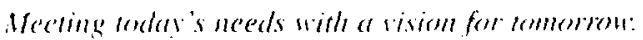

WSRC-RP-97-00761

page 26

cc: WSRC00497

Report Date: August 26, 1997

Page 1 of 2

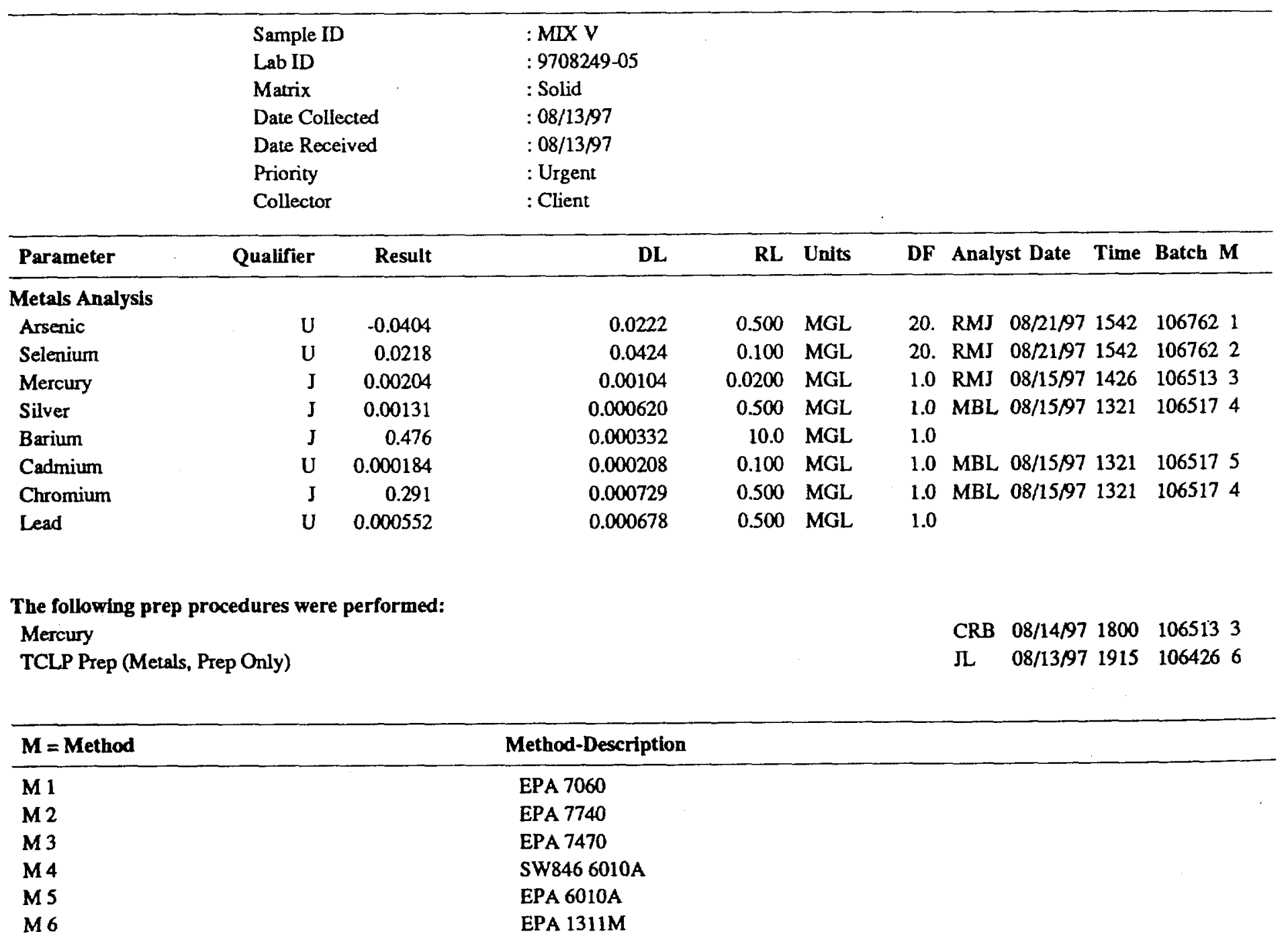


GENERAL ENGINEERING LABORATORIES

Mecting teday's noeds with a vivion for tomonom:

page 27

\begin{tabular}{lll}
\multicolumn{3}{c}{ Laboratory Certifications } \\
STATE & GEL & EPI \\
FL & E87156/87294 & E87472/87458 \\
NC & 233 & \\
SC & 10120 & 10582 \\
TN & 02934 & 02934
\end{tabular}

Client: Westinghouse Savannah River Co. Building 773-58A, Room 1

P.O. Box 616

Aiken, South Carolina 29802

Contact: Ms. Janet Crawford

Project Description: Hazardous Waste Contract

cc: WSRC00497

Report Date: August 26, 1997

Page 2 of 2

\begin{tabular}{lcc}
\hline Sample ID & $:$ MIX V \\
\hline$M=$ Method & Method-Description \\
\hline
\end{tabular}

Notes:

The qualifiers in this report are defined as follows:

ND indicates that the analyte was not detected at a concentration greater than the detection limit.

$J$ indicates presence of analyte at a concentration less than the reporting limir (RL) and greater than the detection limit (DL).

$U$ indicates that the analyte was not detected at a concentration greater than the detection limit.

* indicates that a quality control analyte recovery is outside of specified acceptance criteria.

This data report has been prepared and reviewed

in accordance with General Engineering Laboratories

standard operating procedures. Please direct

any questiong to your Project Manager, Kate Woodward at (803) 769-7376.

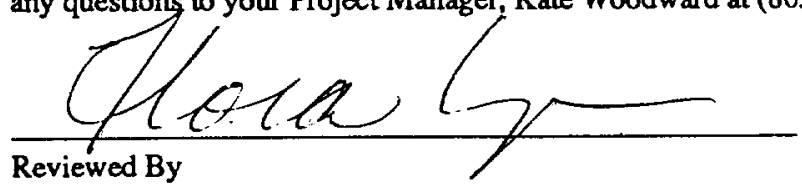




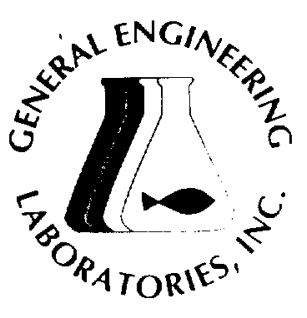

Client: Westinghouse Savannah River Co.

Building 773-58A, Room 1

P.O. Box 616

Aiken, South Carolina 29802

Contact: $\quad$ Ms. Janet Crawford

Project Description:

cc: WSRC00497
WSRC-RP-97-00761

page 28

\section{GENERAL ENGINEERING LABORATORIES}

Mering ledas's needs with a vision for tomomon:

\begin{tabular}{lll}
\multicolumn{3}{c}{ Laboratory Certifications } \\
STATE & GEL & EPI \\
FL & E87156/87294 & E87472/87458 \\
NC & 233 & \\
SC & 10120 & 10582 \\
TN & 02934 & 02934
\end{tabular}

Hazardous Waste Contract

Report Date: August 26, 1997

Page 1 of 2

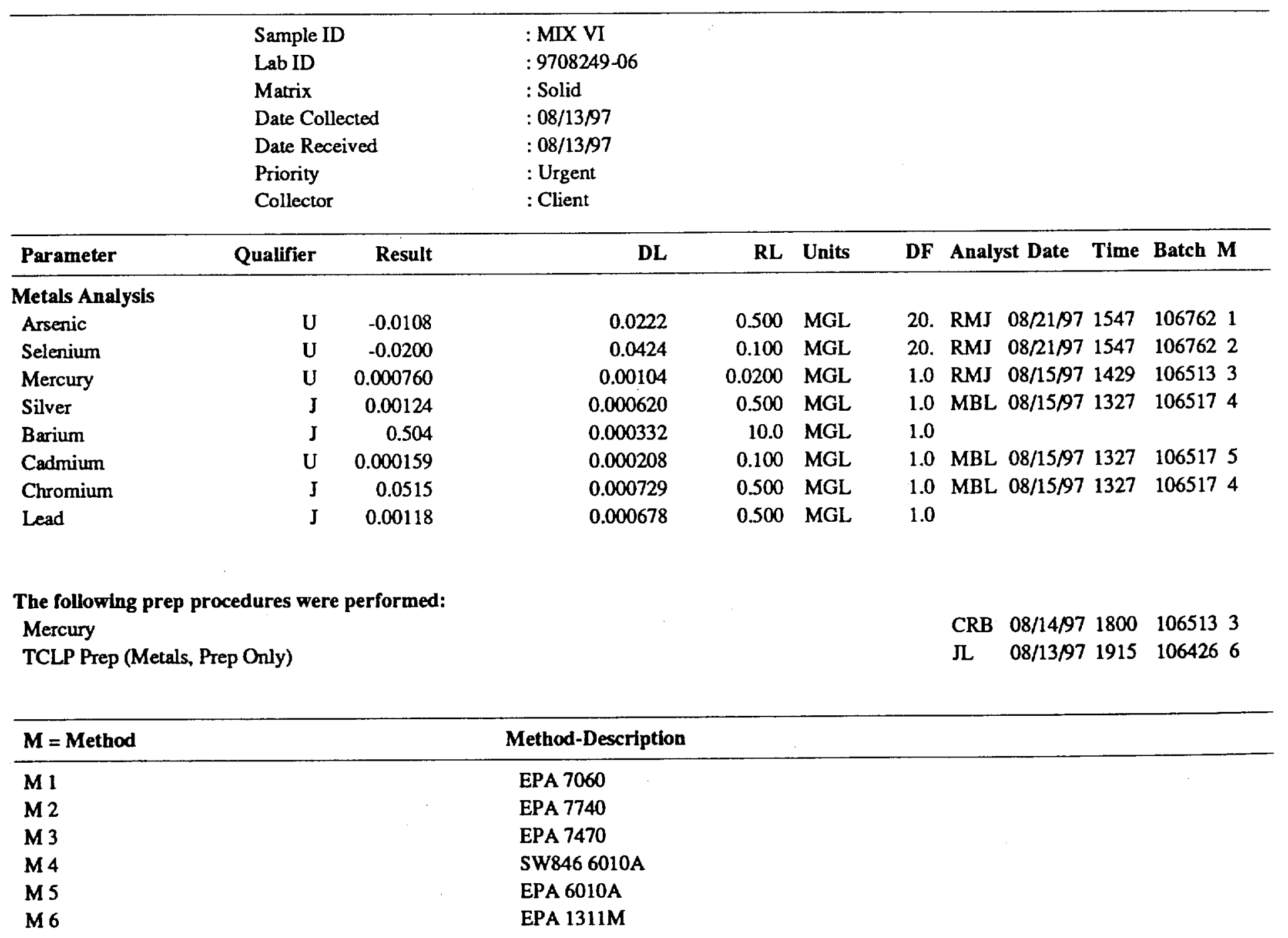




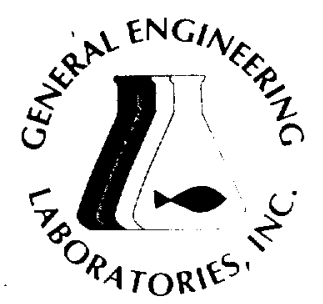

\author{
Mecting todar's needs with a vision for tomorrou:
}

\section{GENERAL ENGINEERING LABORATORIES}

page 29

\begin{tabular}{lll}
\multicolumn{3}{c}{ Laboratory Certifications } \\
STATE & GEL & EPI \\
FL & E87156/87294 & E87472/87458 \\
NC & 233 & \\
SC & 10120 & 10582 \\
TN & 02934 & 02934
\end{tabular}

Client: Westinghouse Savannah River Co.

Building 773-58A, Room 1

P.O. Box 616

Aiken, South Carolina 29802

Contact: Ms. Janet Crawford

Project Description: Hazardous Waste Contract

cc: WSRC00497

Report Date: August 26, 1997

Page 2 of 2

\begin{tabular}{lll}
\hline & Sample ID & MIX VI \\
\hline$M=$ Method & Method-Description & \\
\hline
\end{tabular}

Notes:

The qualifiers in this report are defined as follows:

ND indicates that the analyte was not detected at a concentration greater than the detection limit.

$J$ indicates presence of analyte at a concentration less than the reporting limit (RL) and greater than the detection limit (DL).

$\mathrm{U}$ indicates that the analyte was not detected at a concentration greater than the detection limit.

* indicates that a quality control analyte recovery is outside of specified acceptance criteria.

This data report has been prepared and reviewed

in accordance with General Engineering Laboratories

standard operating procedures. Please direct

any questions to your Project Manager, Kate Woodward at (803) 769-7376.

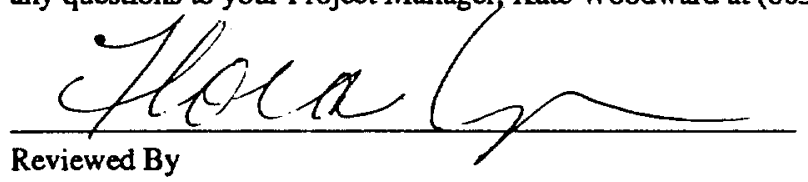




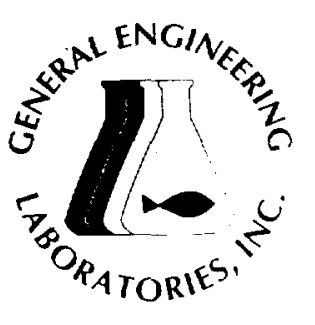

Client: Westinghouse Savannah River Co.

Building 773-58A, Room 1

P.O. Box 616

Aiken, South Carolina 29802

Contact: $\quad$ Ms. Janet Crawford

Project Description:

cc: WSRC00497
WSRC-RP-97-00761

page 30

\section{GENERAL ENGINEERING LABORATORIES}

Mering todar's needs with a vivion for tomonrom:

$\begin{array}{ll}\text { Sample ID } & : \text { SAMPLE 3 } \\ \text { Lab ID } & : 9708249-07 \\ \text { Matrix } & : \text { Solid } \\ \text { Date Collected } & : 08 / 13 / 97 \\ \text { Date Received } & : 08 / 13 / 97 \\ \text { Priority } & : \text { Urgent } \\ \text { Collector } & : \text { Client }\end{array}$

\begin{tabular}{|c|c|c|c|c|c|c|c|c|c|}
\hline Parameter & Qualifier & Result & DL & RL & Units & DF & Analyst Date & Time & Batch $\mathbf{M}$ \\
\hline \multicolumn{10}{|c|}{ Metals Analysis } \\
\hline Arsenic & & 0.896 & 0.0222 & 0.500 & MGL & 20. & RMJ $08 / 21 / 97$ & 1552 & 1067621 \\
\hline Selenium & $\mathbf{J}$ & 0.0568 & 0.0424 & 0.100 & MGL & 20. & RMJ $\quad 08 / 21 / 97$ & 1552 & 1067622 \\
\hline Mercury & $\mathrm{U}$ & 0.000950 & 0.00104 & 0.0200 & MGL & 1.0 & RMJ $08 / 15 / 97$ & 1431 & 1065133 \\
\hline Silver & $\mathbf{J}$ & 0.000976 & 0.000620 & 0.500 & MGL & 1.0 & MBL $08 / 15 / 97$ & 1332 & 1065174 \\
\hline Barium & J & 0.270 & 0.000332 & 10.0 & MGL & 1.0 & & & \\
\hline Cadmium & $\mathrm{J}$ & 0.000274 & 0.000208 & 0.100 & MGL & 1.0 & MBL $08 / 15 / 97$ & 1332 & 1065175 \\
\hline Chromium & $\mathbf{J}$ & 0.0130 & 0.000729 & 0.500 & MGL & 1.0 & MBL $08 / 15 / 97$ & 1332 & 1065174 \\
\hline Lead & $\mathbf{J}$ & 0.00121 & 0.000678 & 0.500 & MGL & 1.0 & & & \\
\hline
\end{tabular}

The following prep procedures were performed:

Mercury

TCLP Prep (Metals, Prep Only)
CRB $08 / 14 / 97 \quad 1800 \quad 1065133$

JL $\quad 08 / 13 / 971915 \quad 1064266$

\begin{tabular}{ll}
\hline M Method & Method-Description \\
\hline M1 & EPA 7060 \\
M2 & EPA 7740 \\
M3 & EPA 7470 \\
M4 & SW846 6010A \\
M5 & EPA 6010A \\
M6 & EPA 1311M
\end{tabular}


WSRC-RP-97-00761

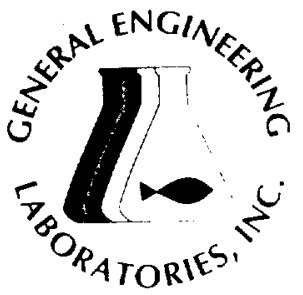

\title{
GENERAL ENGINEERING LABORATORIES
}

\author{
Macring woday's needs with a vision for tomorrow.
}

page 31

\begin{tabular}{lll}
\multicolumn{3}{c}{ Laboratory Certifications } \\
STATE & GEL & EPI \\
FL & E87156/87294 & E87472/87458 \\
NC & 233 & \\
SC & 10120 & 10582 \\
TN & 02934 & 02934
\end{tabular}
: SAMPLE 3

Notes:

The qualifiers in this report are defined as follows:

ND indicates that the analyte was not detected at a concentration greater than the detection limit.

$J$ indicates presence of analyte at a concentration less than the reporting limit (RL) and greater than the detection limit (DL).

$U$ indicates that the analyte was not detected at a concentration greater than the detection limit.

* indicates that a quality control analyte recovery is outside of specified acceptance criteria.

This data report has been prepared and reviewed

in accordance with General Engineering Laboratories

standard operating procedures. Please direct

any questions to your Project Manager, Kate Woodward at (803) 769-7376.

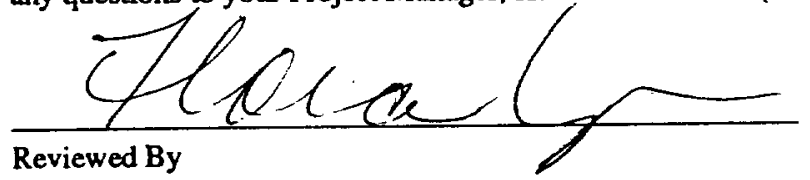




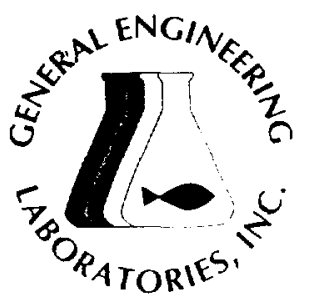

GENERAL ENGINEERING LABORATORIES

Mecting dedar's needs with a rision for tommorm.
WSRC-RP-97-00761

page 32

Client: Westinghouse Say annah River Co. Building 773-58A, Room 1 P.O. Box 616 Aiken, South Carolina 29802

Contact: Ms. Janet Crawford

Project Description: Hazardous Waste Contract cc: WSRC00497

Report Date: August 26, 1997

Page 1 of 2

$\begin{array}{ll}\text { Sample ID } & : \text { SAMPLE 4 } \\ \text { Lab ID } & : 9708249-08 \\ \text { Matrix } & : \text { Solid } \\ \text { Date Collected } & : 08 / 13 / 97 \\ \text { Date Received } & : 08 / 13 / 97 \\ \text { Priority } & : \text { Urgent } \\ \text { Collector } & : \text { Client }\end{array}$

\begin{tabular}{|c|c|c|c|c|c|c|c|c|c|}
\hline Parameter & Qualifier & Result & DL & $\mathbf{R L}$ & Units & DF & Analyst Date & Time & Batch $\mathbf{M}$ \\
\hline \multicolumn{10}{|c|}{ Metals Analysis } \\
\hline Arsenic & $\mathrm{J}$ & 0.0270 & 0.0222 & 0.500 & MGL & 20. & RMJ $08 / 21 / 97$ & 1557 & 1067621 \\
\hline Selenium & $\mathbf{U}$ & 0.0330 & 0.0424 & 0.100 & MGL & 20. & RMJ $08 / 21 / 97$ & 1557 & 1067622 \\
\hline Mercury & $\mathbf{U}$ & 0.000110 & 0.00104 & 0.0200 & MGL & 1.0 & RMJ 08/15/97 & 1434 & 1065133 \\
\hline Silver & $\mathrm{J}$ & 0.00103 & 0.000620 & 0.500 & MGL & 1.0 & MBL 08/15/97 & 1337 & 1065174 \\
\hline Barium & J & 0.182 & 0.000332 & 10.0 & MGL & 1.0 & & & \\
\hline Cadmium & $J$ & 0.00117 & 0.000208 & 0.100 & MGL & 1.0 & MBL $08 / 15 / 97$ & 1337 & 1065175 \\
\hline Chromium & J & 0.00859 & 0.000729 & 0.500 & MGL & 1.0 & MBL 08/15/97 & 1337 & 1065174 \\
\hline Lead & J & 0.000927 & 0.000678 & 0.500 & MGL & 1.0 & & & \\
\hline
\end{tabular}

The following prep procedures were performed:

Mercury

CRB $\quad 08 / 14 / 97 \quad 1800 \quad 1065133$

TCLP Prep (Metals, Prep Only)

\begin{tabular}{ll}
\hline M Method & Method-Description \\
\hline M1 & EPA 7060 \\
M2 & EPA 7740 \\
M3 & EPA 7470 \\
M4 & SW846 6010A \\
M5 & EPA 6010A \\
M6 & EPA 1311M
\end{tabular}




\author{
Client: Westinghouse Savannah River Co. \\ Building 773-58A, Room 1 \\ P.O. Box 616 \\ Aiken, South Carolina 29802 \\ Contact: Ms. Janet Crawford
}

Project Description: Hazardous Waste Contract

cc: WSRC00497

Report Date: August 26, 1997

Page 2 of 2

Sample ID : SAMPLE 4

M = Method Method-Description

Notes:

The qualifiers in this report are defined as follows:

ND indicates that the analyte was not detected at a concentration greater than the detection limit.

$J$ indicates presence of analyte at a concentration less than the reporting limit (RL) and greater than the detection limit (DL).

$U$ indicates that the analyte was not detected at a concentration greater than the detection limit.

* indicates that a quality control analyte recovery is outside of specified acceptance criteria.

This data report has been prepared and reviewed

in accordance with General Engineering Laboratories

standard operating procedures. Please direct

any questions to your Project Manager, Kate Woodward at (803) 769-7376.

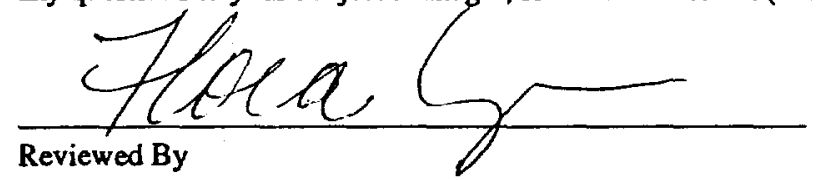


Project Description: Hazardous Waste Contract

cc: WSRC00497

Lab. Sample ID: $9708249 \%$
Report Date: August 26, 1997

Page 1 of 2

\begin{tabular}{|c|c|c|c|c|c|c|c|c|c|c|c|c|}
\hline Sample/Paran & Type & Batch & NOM & Sample & Qual QC & Units & RPD\% & REC\% & Range & Analyst & Date & Time \\
\hline \multicolumn{13}{|c|}{ Metals Analysis } \\
\hline QC450042 & BLANK & 106762 & & & & & & & & & & \\
\hline Arsenic & & & & & -0.000590 & MGL & & & & RMJ & $08 / 21 / 97$ & 71516 \\
\hline Selenium & & & & & 0.000940 & MGL & & & & & & \\
\hline QC450043 & BLANK & 106762 & & & & & & & & & & \\
\hline Arsenic & & & & & -0.00251 & MGL & & & & RMJ & $08 / 21 / 97$ & 71612 \\
\hline Selenium & & & & & 0.00272 & MGL & & & & & & \\
\hline QC450046 & LCS & 106762 & & & & & & & & & & \\
\hline Arsenic & & & 0.04 & & 0.0357 & MGL & & 89.2 & $(80.0-120)$. & .) $\mathrm{RMJ}$ & $08 / 21 / 97$ & 1510 \\
\hline Selenium & & & 0.04 & & 0.0376 & MGL & & 94.1 & $(80.0-120)$. & & & \\
\hline QC450044 & 9708249-07MS & 106762 & & & & & & & & & & \\
\hline Arsenic & & & 0.8 & 0.896 & 1.48 & MGL & & 73.0 & & RMJ & $08 / 21 / 97$ & 71617 \\
\hline Selenium & & & 0.8 & 0.0568 & 0.694 & MGL & & 79.7 & & & & \\
\hline QC450045 & 9708249-07MSD & 106762 & & & & & & & & & & \\
\hline Arsenic & & & 0.8 & 0.896 & 1.47 & MGL & 1.87 & 71.6 & & RMJ & $08 / 21 / 97$ & 1624 \\
\hline Selenium & & & 0.8 & 0.0568 & 0.710 & MGL & 2.39 & 81.6 & & & & \\
\hline QC449092 & BLANK & 106513 & & & & & & & & & & \\
\hline Mercury & & & & & -0.000100 & MGL & & & & RMJ & $08 / 15 / 97$ & 71441 \\
\hline QC449093 & BLANK & 106513 & & & & & & & & & & \\
\hline Mercury & & & & & $-9.00 \mathrm{E}-05$ & MGL & & & & RMJ & $08 / 15 / 97$ & 1443 \\
\hline QC449105 & 9708249-01 DUP & 106513 & & & & & & & & & & \\
\hline Mercury & & & & 0.00 & $-5.00 \mathrm{E}-05$ & MGL & 0.00 & & & RMJ & $08 / 15 / 97$ & 1522 \\
\hline QC449106 & LCS & 106513 & & & & & & & & & & \\
\hline Mercury & & & 0.02 & & 0.0204 & MGL & & 102 & $(77.7-123)$. & .) $\mathrm{RMJ}$ & $08 / 15 / 97$ & 71524 \\
\hline QC449107 & LCS DUP & 106513 & & & & & & & & & & \\
\hline Mercury & & & 0.02 & & 0.0212 & MGL & 3.85 & 106 & $(0.00-23.3)$ & ) $\mathrm{RMJ}$ & $08 / 15 / 97$ & 71527 \\
\hline QC449103 & 9708249-01MS & 106513 & & & & & & & & & & \\
\hline Mercury & & & 0.02 & 0.00 & 0.0263 & MGL & & 132 & & RMJ & $08 / 15 / 97$ & 71517 \\
\hline QC449104 & 9708249-01MSD & 106513 & & & & & & & & & & \\
\hline Mercury & & & 0.02 & 0.00 & 0.0246 & MGL & 6.68 & 123 & & RMJ & $08 / 15 / 97$ & 71519 \\
\hline QC449116 & BLANK & 106517 & & & & & & & & & & \\
\hline Barium & & & & & 0.0426 & MGL & & & & MBL & $08 / 15 / 97$ & 71215 \\
\hline Cadmium & & & & & 0.000157 & MGL & & & & & & \\
\hline Chromium & & & & & 0.00110 & MGL & & & & & & \\
\hline Lead & & & & & 0.000933 & MGL & & & & & & \\
\hline Silver & & & & & 0.000266 & MGL & & & & & & \\
\hline QC449117 & BLANK & 106517 & & & & & & & & & & \\
\hline Barium & & & & & 0.000424 & MGL & & & & MBL & $08 / 15 / 97$ & 71221 \\
\hline Cadmium & & & & & 0.000125 & MGL & & & & & & \\
\hline Chromium & & & & & 0.00102 & MGL & & & & & & \\
\hline
\end{tabular}


Project Description: Hazardous Waste Contract

cc: WSRC00497

\begin{tabular}{|c|c|c|}
\hline Sample/Para & ameter & Batch \\
\hline $\begin{array}{l}\text { Lead } \\
\text { Silver }\end{array}$ & & \\
\hline $\begin{array}{l}\text { QC449119 } \\
\text { Barium } \\
\text { Cadmium } \\
\text { Chromium } \\
\text { Lead } \\
\text { Silver }\end{array}$ & 9708249-08DUP & 106517 \\
\hline $\begin{array}{l}\text { QC449118 } \\
\text { Barium } \\
\text { Cadmium } \\
\text { Chromium } \\
\text { Lead } \\
\text { Silver }\end{array}$ & LCS & 106517 \\
\hline $\begin{array}{l}\text { QC449121 } \\
\text { Barium } \\
\text { Cadmium } \\
\text { Chromium } \\
\text { Lead } \\
\text { Silver }\end{array}$ & 9708249-08MS & 106517 \\
\hline $\begin{array}{l}\text { QC449120 } \\
\text { Barium } \\
\text { Cadmium } \\
\text { Chromium } \\
\text { Lead }\end{array}$ & 9708249-08SERIAL & 106517 \\
\hline
\end{tabular}

Report Date: August 26, 1997

Page 2 of 2

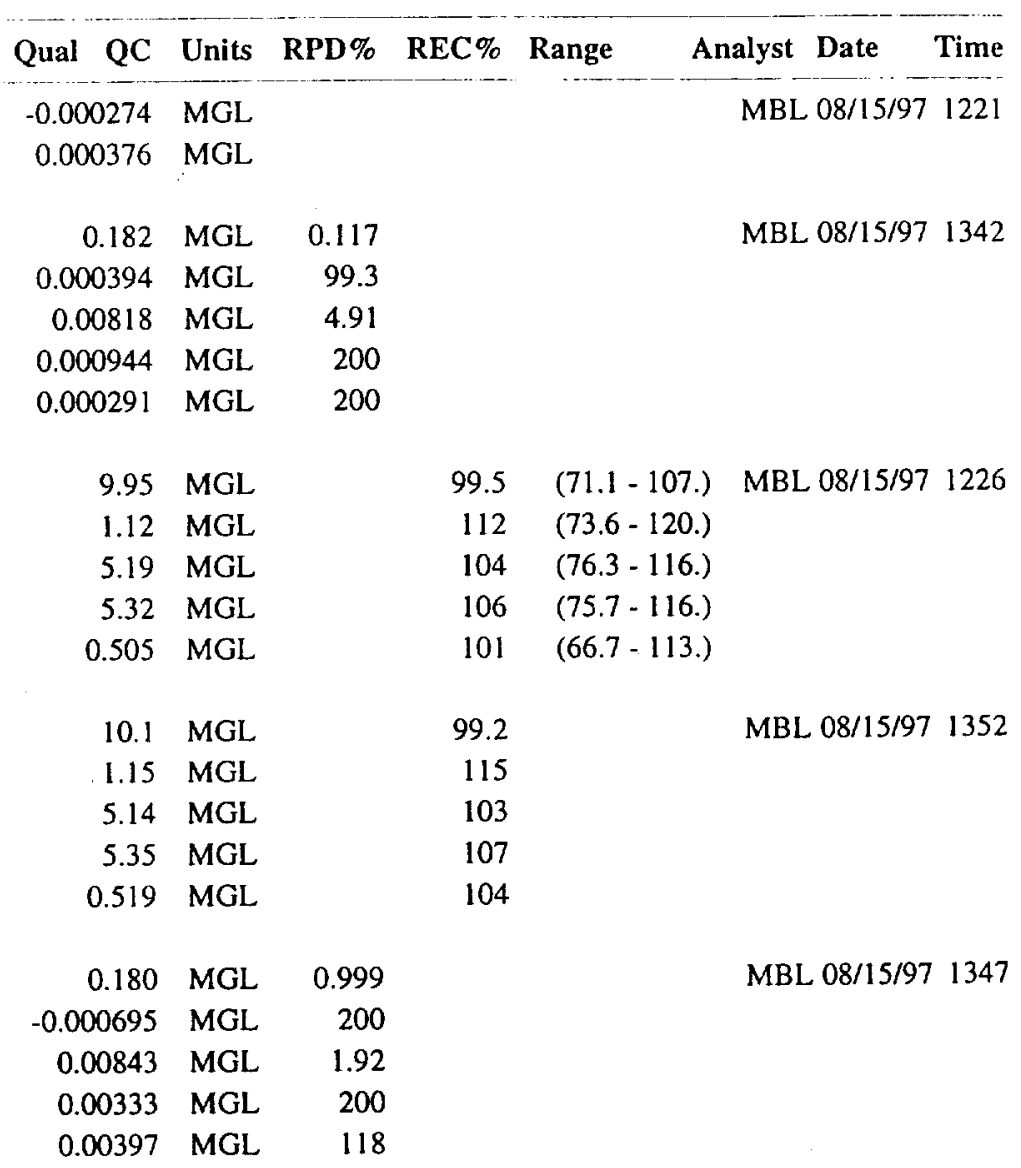

$0.00397 \mathrm{MGL}$

118
99.5 (71.1 - 107.) MBL 08/15/97 1226

99.2

115

104

MBL 08/15/97 1347

Notes:

The qualifiers in this report are defined as follows:

$J$ indicates presence of analyte $<R L$ (Report Limit)

$\mathrm{U}$ indicates presence of analyte $<\mathrm{DL}$ (Detect Limit)

$\mathrm{n} / \mathrm{a}$ indicates that spike recovery limits do not apply when

sample concentration exceeds spike conc by a factor of 4 or more

0.182
0.00117
0.00859
0.000927
0.00103

10

1

5

0.5

10

0.182

0.00117

0.00859

0.000927

$0.5 \quad 0.00103$

0.182

0.00117

0.00859

0.000927

0.00103 


\begin{tabular}{ll} 
EGG150 & \\
Sample & Lab Number \\
\hdashline$-\cdots--$ & $-\cdots-1-$ \\
SAMPLE 3 & $9708249-07$ \\
SAMPLE 4 & $9708249-08$ \\
MIX I & $9708249-01$ \\
MIX II & $9708249-02$ \\
MIX III & $9708249-03$ \\
MIX IV & $9708249-04$ \\
MIX V & $9708249-05$ \\
MIX VI & $9708249-06$
\end{tabular}

page 36 


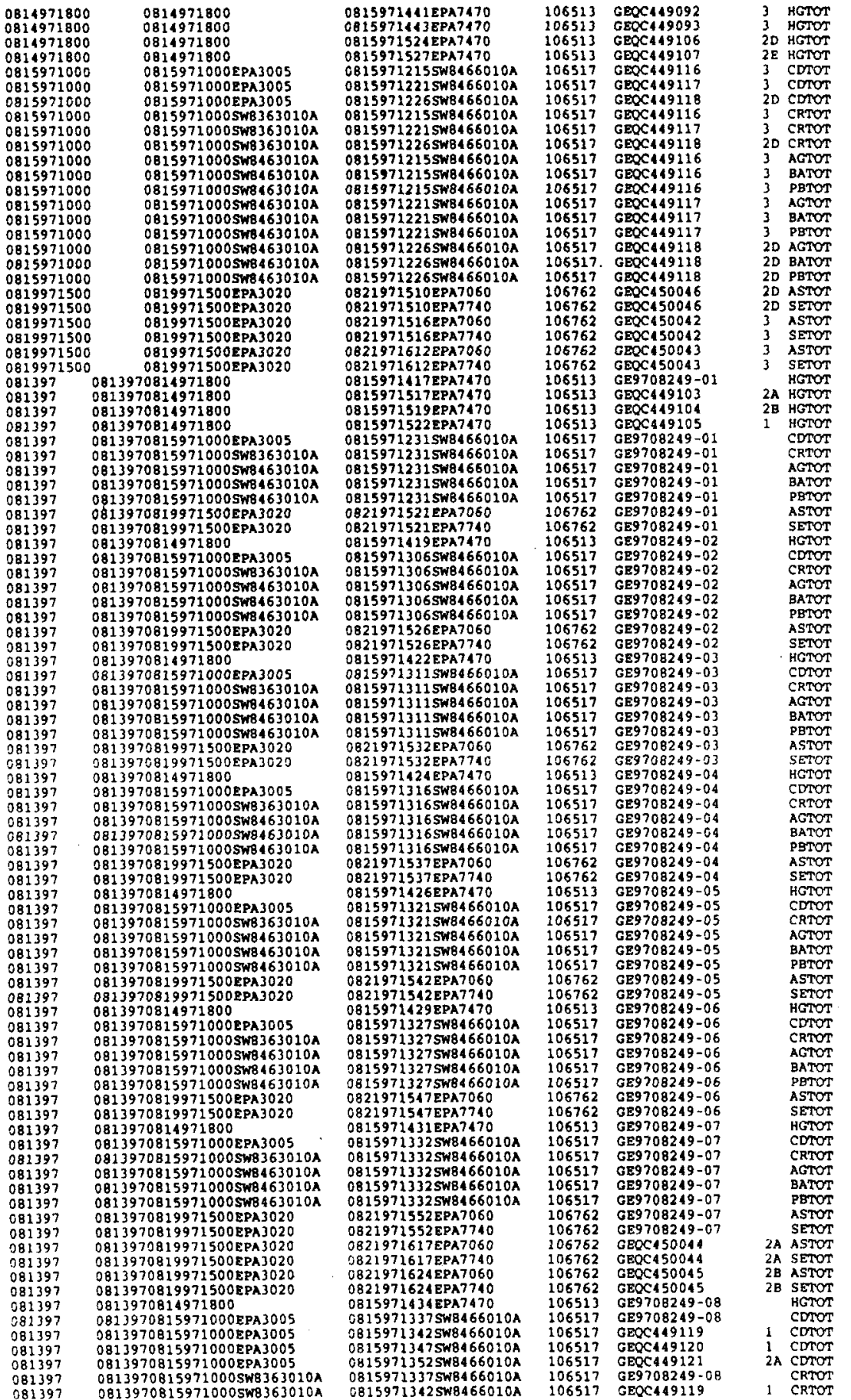

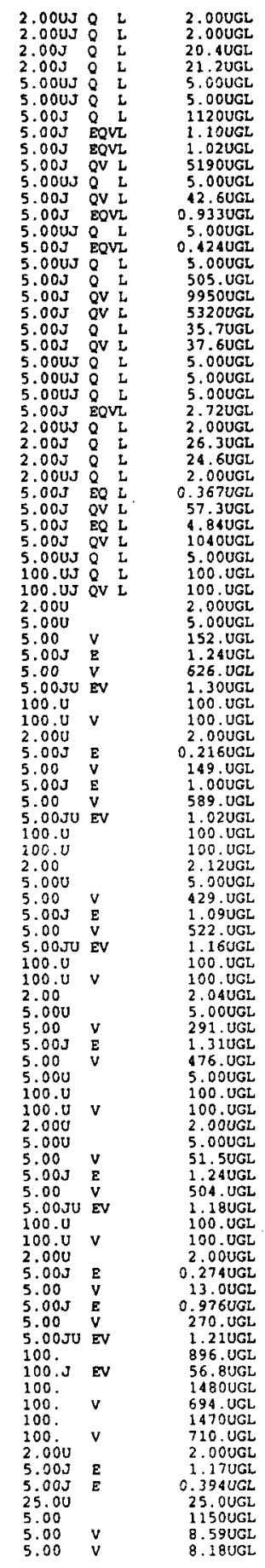

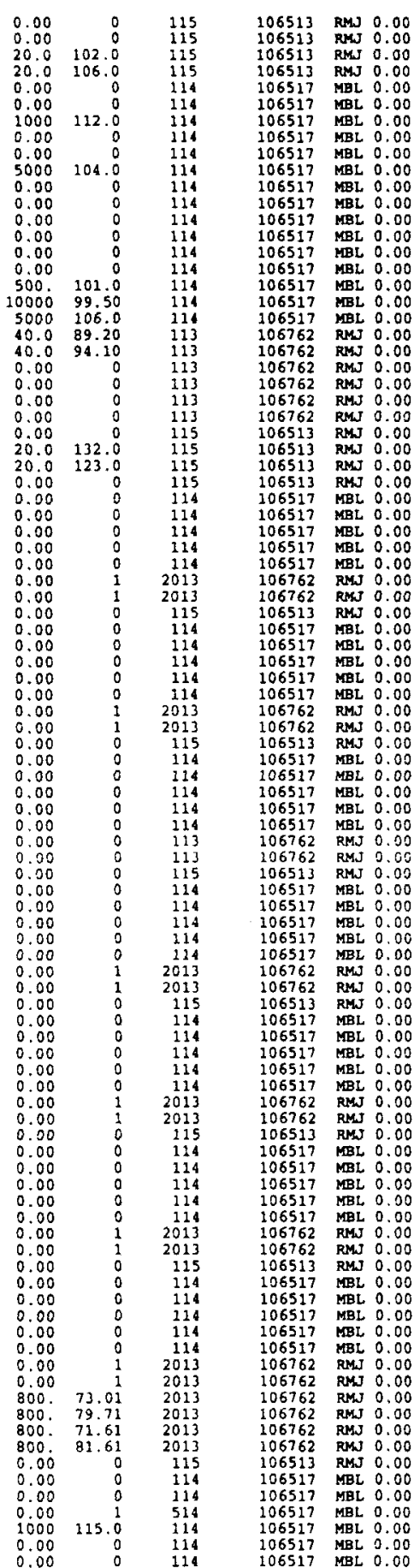

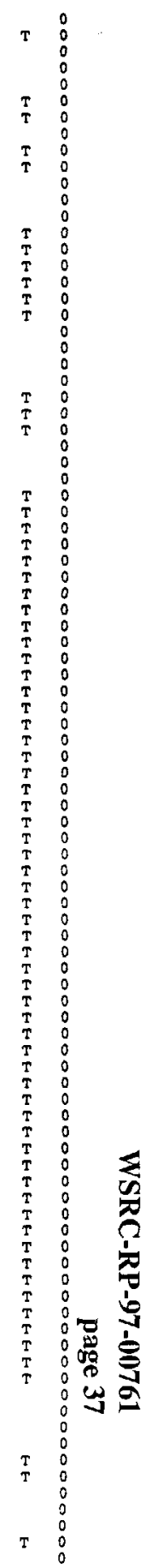




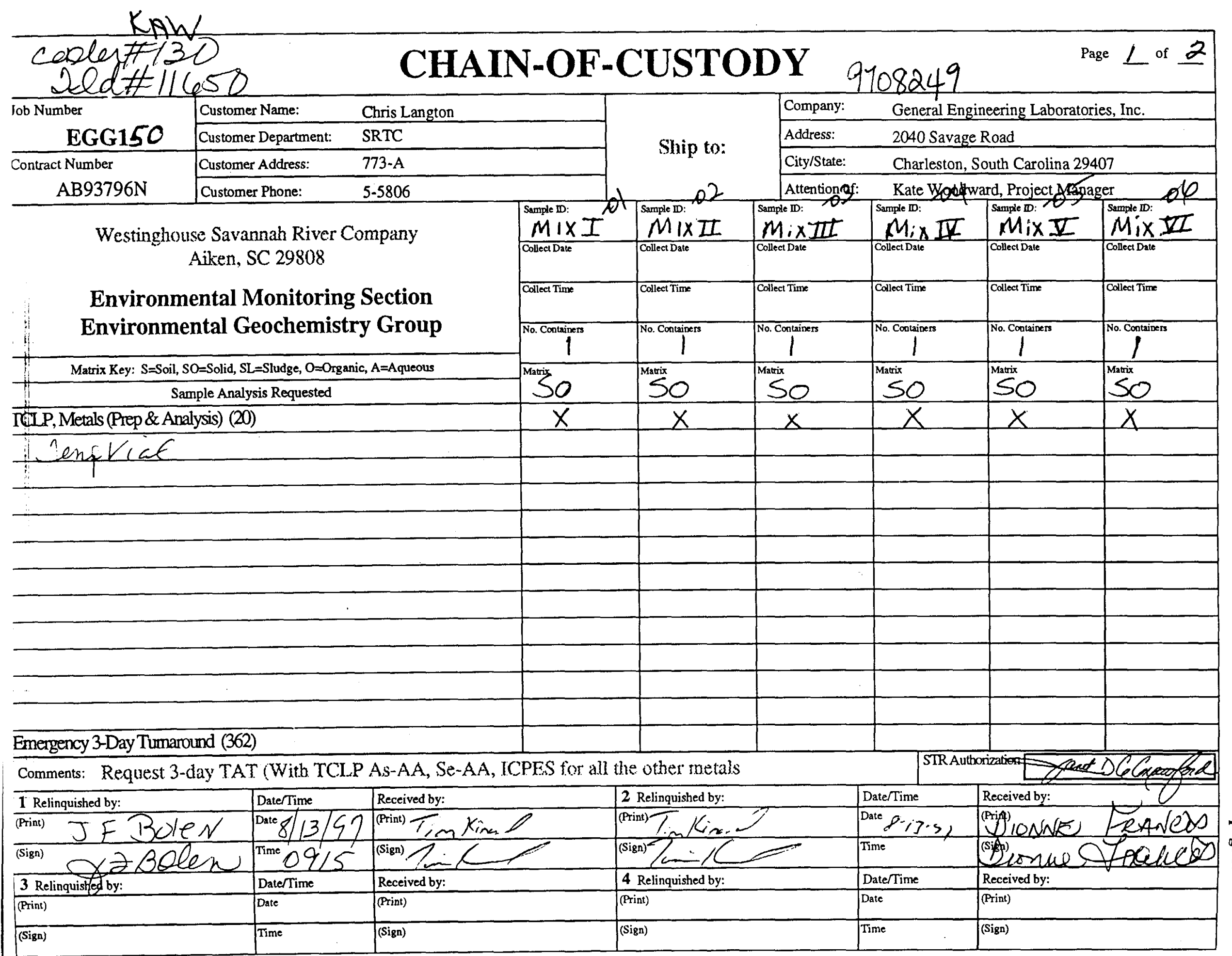




\section{CHAIN-OF-CUSTODY}

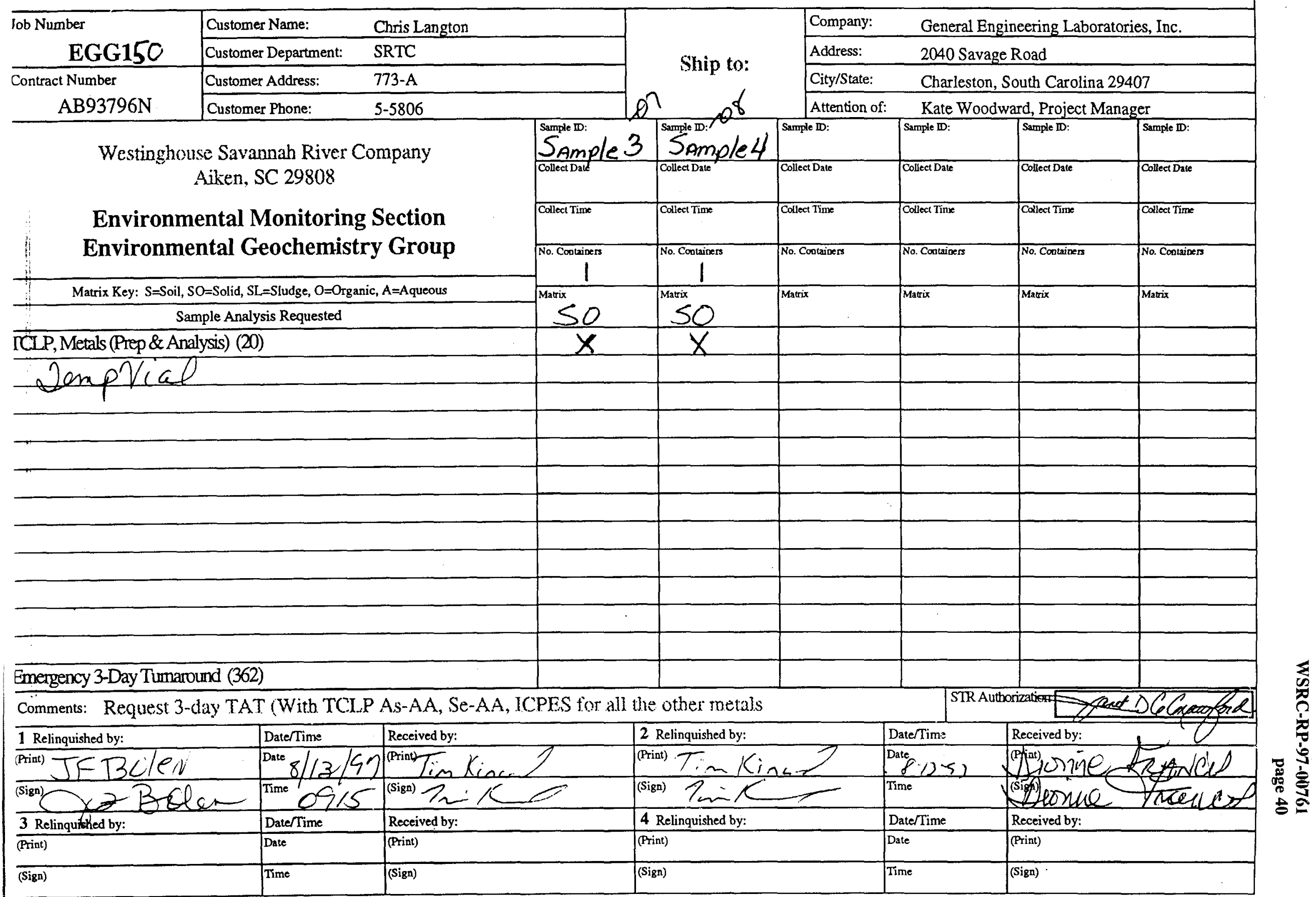


WSRC-RP-97-00761

page 41

Sample Receipt Review WSRC

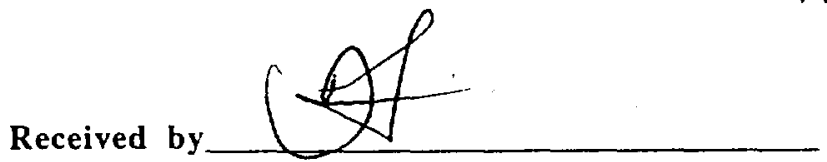

gel cooler \#/30

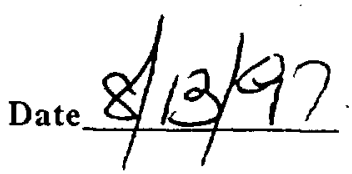

SAMPLE RECEIPT CRITERIA

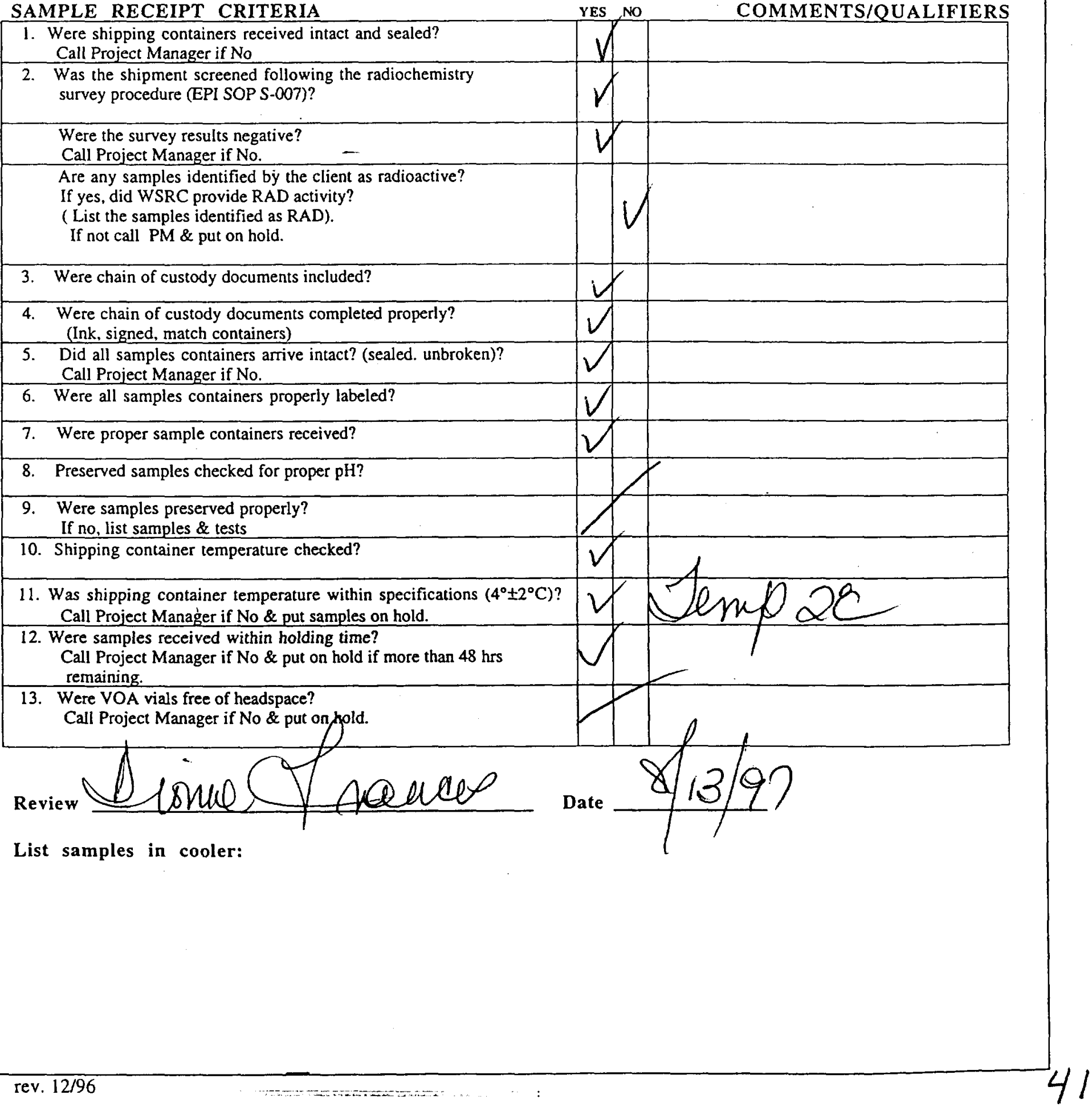


9708249-01.01 - Other 13-AUG-97 15:47:31

13-AUG-97 16:24:58 Dionne Francis

13-AUG-97 16:26:17 Jianguo Li

13-AUG-97 19:21:33 Jianguo Li

186251 - $1000 \mathrm{ml} / \mathrm{P}$

13-AUG-97 $16: 26: 50$

14-AUG-97 $17: 57: 51$

15-AUG-97 $08: 36: 32$

15-AUG-97 08:50:38

15-AUG-97 10:26:00

15-AUG-97 $10: 46: 57$

15-AUG-97 13:58:23

19-AUG-97 15:08:25

$186389-50 \mathrm{ml} / \mathrm{P}$

15-AUG-97 08:36:57 Christy Blumbardt

$186909-50 \mathrm{ml} / \mathrm{P}$

19-AUG-97 15:10:04 Frankie Davis

21-AUG-97 12:32:41 Rose Jenkins

9708249-02.01 - Other

13-AUG-97 15:47:31 Dionne Francis

13-AUG-97 16:24:57 Dionne Francis

13-AUG-97 16:26:17 Jianguo Li

13-AUG-97 19:21:32 Jianguo Li

$186250-1000 \mathrm{ml} / \mathrm{P}$

13-AUG-97 16:26:48

14-AUG-97 17:57:51

15-AUG-97 08:36:32

15-AUG-97 08:50:38

15-AUG-97 10:19:31

15-AUG-97 10:46:58

15-AUG-97 13:58:23

19-AUG-97 15:08:25

$J$ ianguo Li

Christy Blumhardt

Christy Blumhardt

Christy Blumhardt

Christy Blumhardt

Melinda Lewis

Rose Jenkins

Frankie Davis
- > Rad Cooler

- $\rightarrow$ Sample Delivery

$-\rightarrow$ TCLP Prep

$-\rightarrow$ Consumed by Analysis

$-\rightarrow$ TCLP Prep

--> Inorganic Prep

--> Inorganic Prep

$-\rightarrow$ Mercury lab

$-\rightarrow$ Inorganic Prep

- ICP lab

--> Mercury lab

--> Inorganic Prep

$186390-50 \mathrm{ml} / \mathrm{P}$

15-AUG-97 08:37:05 Christy Blumhardt

$-\rightarrow$ Inorganic Prep

$\rightarrow$ GFAA lab

- Rad Cooler

-> Sample Delivery

$-\rightarrow$ TCLP Prep

- $\rightarrow$ Consumed by Analysis

$\rightarrow->$ TCLP Prep

$-\rightarrow$ Inorganic Prep

- In Inorganic Prep

- Mercury lab

$-\rightarrow$ Inorganic Prep

- ICP lab

- Mercury lab

--> Inorganic Prep

186907 - $50 \mathrm{ml} / \mathrm{P}$

19-AUG-97 15:09:37 Frankie Davis

21-AUG-97 12:32:42 Rose Jenkins

--> Inorganic Prep

$->$ GFAA lab

9708249-03.01 - Other

13-AUG-97 15:47:31 Dionne Francis

- Rad Cooler

13-AUG-97 16:24:58 Dionne Erancis

-> Sample Delivery

13-AUG-97 16:26:17 Jianguo Li

- TCLP Prep

13-AUG-97 19:21:33 Jianguo Li

- Consumed by Analysis 
$186249-1000 \mathrm{ml} / \mathrm{P}$

13-AUG-97 16:26:46

14-AUG-97 17:57:51

15-AUG-97 08:36:32

15-AUG-97 08:50:38

15-AUG-97 10:19:31

15-AUG-97 10:46:58

15-AUG-97 13:58:23

19-AUG-97 15:08:25

$186391-50 \mathrm{ml} / \mathrm{P}$

15-AUG-97 08:37:25 Christy Blumhardt

$186906-50 \mathrm{ml} / \mathrm{P}$

19-AUG-97 15:09:29 Frankie Davis

21-AUG-97 12:32:42 Rose Jenkins

9708249-04.01 - other

13-AUG-97 16:25:11

13-AUG-97 16:25:32 Dionne Francis

13-AUG-97 16:26:17 Jianguo Li

13-AUG-97 19:21:33 Jianguo Li

$186248-1000 \mathrm{ml} / \mathrm{P}$

13-AUG-97 16:26:46

14-AUG-97 $17: 57: 50$

15-AUG-97 08:36:32

15-AUG-97 08:50:38

15-AUG-97 10:19:30

15-AUG-97 10:19:30

15-AUG-97 10:46:59

15-AUG-97 13:58:23

19-AUG-97 15:08:25

$J$ ianguo $\mathrm{Li}$

Christy Blumhardt

Christy Blumhardt

Christy Blumbardt

Christy Blumhardt

Christy Blumbardt

Melinda Lewis

Rose Jenkins

Frankie Davis $\rightarrow$ TCLP Prep

-> Inorganic Prep

-> Inorganic Prep

$\rightarrow$ Mercury lab

$\rightarrow$ Inorganic Prep

$-\rightarrow$ ICP lab

$\rightarrow$ Mercury lab

$\rightarrow$ Inorganic Prep

$186392-50 \mathrm{ml} / \mathrm{P}$

15-AUG-97 08:37:33 Christy Blumhardt _-> Inorganic Prep

$186905-50 \mathrm{ml} / \mathrm{P}$

19-AUG-97 15:09:18 Frankie Davis

21-AUG-97 12:32:43 Rose Jenkins

-> Main Cooler

-> Sample Delivery

$-\rightarrow$ TCLP Prep

$-\rightarrow$ Consumed by Analysis

$->$ TCLP Prep

--> Inorganic Prep

--> Inorganic Prep

- Mercury lab

--> Inorganic Prep

$\rightarrow$ Inorganic Prep

$-\rightarrow$ ICP lab

$\rightarrow$ Mercury lab

--> Inorganic Prep

$-\rightarrow$ Inorganic Prep

$\rightarrow$ GFAA lab

9708249-05.01 - Other

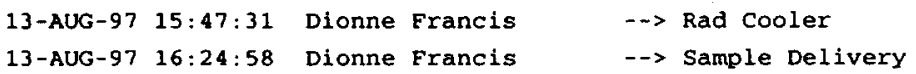

13-AUG-97 16:26:17 Jianguo Li $\rightarrow$ TCLP Prep

13-AUG-97 19:21:33 Jianguo $\mathrm{Li} \quad->$ Consumed by Analysis

$186247-1000 \mathrm{ml} / \mathrm{P}$

13-AUG-97 16:26:45

14-AUG-97 17:57:51 Christy Blumhardt

15-AUG-97 08:36:32 Christy Blumhardt

15-AUG-97 08:50:38 Christy Blumhardt

15-AUG-97 10:19:31 Christy Blumhardt

15-AUG-97 10:46:59 Melinda Lewis

15-AUG-97 13:58:23 Rose Jenkins

19-AUG-97 15:08:25 Frankie Davis

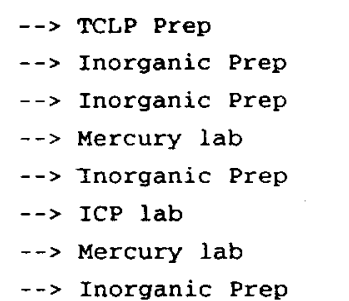


$186393-50 \mathrm{ml} / \mathrm{P}$

15-AUG-97 08:37:46 Christy Blumhardt --> Inorganic Prep

$186910-50 \mathrm{ml} / \mathrm{P}$

19-AUG-97 15:11:00 Frankie Davis --> Inorganic Prep

21-AUG-97 12:32:43 Rose Jenkins -) GFAA lab

9708249-06.01 - Other

13-AUG-97 15:47:31 Dionne Francis

- > Rad Cooler

13-AUG-97 16:24:58 Dionne Francis

- -> Sample Delivery

13-AUG-97 16:26:17 Jianguo $\mathrm{Li}$

--> TCLP Prep

13-AUG-97 19:21:33 Jianguo Li

--> Consumed by Analysis

$186246-1000 \mathrm{ml} / \mathrm{P}$

13-AUG-97 $16: 26: 44$

14-AUG-97 $17: 57: 50$

Jianguo Li

- $>$ TCLP Prep

15-AUG-97 08:36:32

Christy Blumhardt

--> Inorganic Prep

15-AUG-97 $08: 50: 38$

Christy Blumhardt

--> Inorganic Prep

-> Mercury lab

15-AUG-97 10:19:28 Christy Blumhardt

- -> Inorganic Prep

15-AUG-97 10:47:00

Melinda Lewis $\quad$.) ICP lab

15-AUG-97 13:58:23

Rose Jenkins

- > Mercury lab

19-AUG-97 15:08:24

Frankie Davis

- -> Inorganic Prep

$186394-50 \mathrm{ml} / \mathrm{P}$

15-AUG-97 08:37:54 Christy Blumhardt

-> Inorganic Prep

186904 - $50 \mathrm{ml} / \mathrm{P}$

19-AUG-97 15:08:58 Frankie Davis

21-AUG-97 12:32:43 Rose Jenkins

$->$ Inorganic Prep

$\rightarrow$ GFAA lab

9708249-07.01 - other

13-AUG-97 15:47:31 Dionne Francis

$->$ Rad Cooler

13-AUG-97 16:24:58 Dionne Francis

- -> Sample Delivery

13-AUG-97 16:26:17 Jianguo Li

- $\rightarrow$ TCLP Prep

13-AUG-97 19:21:33 Jianguo Li

- $>$ Consumed by Analysis

$186245-1000 \mathrm{ml} / \mathrm{P}$

13-AUG-97 $16: 26: 43$

14-AUG-97 17:57:51

15-AUG-97 $08: 36: 32$

Jianguo $\mathrm{Li}$

- $>$ TCLP Prep

15-AUG-97 OB:50:38

Christy Blumhardt

--> Inorganic Prep

--> Inorganic Prep

-> Mercury lab

15-AUG-97 10:19:30

Christy Blumhard

Christy Blumhardt

-> Inorganic Prep

15-AUG-97 10:47:00

Christy Blumhardt

Melinda Lewis

$\rightarrow$ ICP lab

15-AUG-97 $13: 58: 23$

Rose Jenkins

- Mercury lab

19-AUG-97 15:08:25

Frankie Davis

$\rightarrow$ Inorganic Prep

186395 - $50 \mathrm{ml} / \mathrm{P}$

15-AUG-97 08:38:03 Christy Blumhardt

-> Inorganic Prep

$186911-50 \mathrm{ml} / \mathrm{P}$

19-AUG-97 15:11:14 Frankie Davis

21-AUG-97 12:32:44 Rose Jenkins

-> Inorganic Prep

$->$ GFAA lab 
WSRC-RP-97-00761

page 45

Internal chain of custody

Audit Trail by container

Page: 4

Printed: $08 / 22 / 97 \quad 12: 32$

97082498

Printed: $08 / 22 / 972.12: 32$

9708249-08.01 - Other

13-AUG-97 15:47:31 Dionne Francis

13-AUG-97 16:24:58 Dionne Francis

- Rad cooler

13-AUG-97 16:26:17 Jianguo $\mathrm{Li}$

$->$ Sample Delivery

13-AUG-97 19:21:33 Jianguo Li

-> TCLP Prep

$-\rightarrow$ Consumed by Analysis

$186244-1000 \mathrm{ml} / \mathrm{P}$

13-AUG-97 16:26:42 Jianguo Li

$\rightarrow$ TCLP Prep

14-AUG-97 17:57:50 Christy Blumhardt

15-AUG-97 08:36:32 Christy Blumhardt

15-AUG-97 08:50:38 Christy Blumhardt

15-AUG-97 10:19:30 Christy Blumhardt

15-AUG-97 10:16:59 Melinda Lewis

15-AUG-97 13:58:23 Rose Jenkins

$\rightarrow$ Inorganic Prep

- $>$ Inorganic Prep

-> Mercury lab

$-\rightarrow$ Inorganic Prep

$->$ ICP $1 \mathrm{ab}$

$->$ Mercury lab

$\rightarrow$ Inorganic Prep

$186396-50 \mathrm{ml} / \mathrm{P}$

15-AUG-97 08:38:14 Christy Blumhardt --> Inorganic Prep

$186908-50 \mathrm{ml} / \mathrm{P}$

19-AUG-97 15:09:46 Frankie Davis $\quad->$ Inorganic Prep

21-AUG-97 12:32:44 Rose Jenkins $\quad->$ GFAA $1 \mathrm{ab}$ 